ISSN: 0213-2079 - ISSN electrónico: 2386-3889

DOI: https://doi.org/10.14201/shhmo2018402199231

\title{
PRENSA ECONÓMICA DE LA ILUSTRACIÓN ESPAÑOLA $(1758-1792)^{*}$
}

\section{Journalism on Political Economy of the Spanish Enlighten- ment (1758-1792)}

Jesús ASTIGARRAGA

Universidad de Zaragoza

RESUMEN: Este trabajo aborda una revisión sistemática de la prensa económica de la Ilustración española entre 1758 y 1792. Además de identificarla, trata de descubrir sus fuentes, de demarcar sus etapas en torno a dos períodos diferenciados (1758-1771 y 1776-1792) y de ubicar sus contenidos en las corrientes doctrinales de su época. A la sombra de las iniciativas periodísticas de este periodo, fue emergiendo una prensa de una inspiración doctrinal plural. Su influjo principal procedió de fuentes periodísticas francesas, y su culminación se alcanzó con el inicio de la publicación en 1792 de El Correo Mercantil. Este trabajo también subraya el papel central en todo ello de los publicistas relacionados con la Sociedad Matritense y la Junta de Comercio. A ellos se responsabiliza de las mejoras que conoció en ese período una prensa económica que instigó la creación de un nuevo «público» y fue aproximándose de forma paulatina a la de otras naciones del entorno más cercano.

Palabras clave: Circulación internacional de las ideas; historia del pensamiento económico; Ilustración española; historia de la prensa; prensa económica.

* Este trabajo se integra en los Proyectos HAR2016-77344-R y H26_17R. El autor agradece los comentarios recibidos por los evaluadores anónimos del trabajo, que han servido para mejorar significativamente su calidad.

Ediciones Universidad de Salamanca / 요 Stud. his., H. ${ }^{a}$ mod., 40, n. 2 (2018), pp. 199-231 
ABSTRACT: This article presents a systematic review of the economic journalism of the Spanish Enlightenment between 1758 and 1792. In addition to identifying this type of journalism, it aims at discovering its sources, determining its main phases around two distinct periods (1758-1771 and 1776-1792), and locating its contents within the doctrinal trends of its time. In the shadow of the journalistic initiatives of this period, a journalism of a plural doctrinal inspiration emerged. It was based on the influence of French journalistic sources. Its culmination was reached in 1792, with the beginning of the publication of El Correo Mercantil. This article also underlines the central role of the publicists of the Madrid Economic Society and the Board of Trade. They were responsible of the improvements experienced in that period by an economic journalism that instigated the creation of a new «public» and gradually approached the journalism developed in other nearby nations.

Key words: International Circulation of Ideas; History of Economic Thought; Spanish Enlightenment; History of Journalism; Journals on Political Economy.

\section{INTRODUCCIÓN}

Es indiscutible que la prensa representó un campo muy activo en la recepción y la difusión de las ideas ilustradas en la España del siglo XVIII. Fue, en particular, durante los años sesenta cuando se produjo una primera eclosión de gacetas, cartas, misceláneas o mercurios, que compartían una misma voluntad de difundir los saberes útiles en públicos amplios a través de la entrega periódica de sus ejemplares. No extraña, por ello, que su análisis haya reunido una línea privilegiada de los estudios de historia cultural de la Ilustración española ${ }^{1}$. Esta cuestión resulta evidente en temas como las ideas literarias o la crítica social y de las costumbres,

1. Sin ánimo de exhaustividad, en cuanto a las fuentes, son particularmente importantes: Sempere, J.: Ensayo de una biblioteca española de los mejores escritores del reinado de Carlos III. Madrid, 1787, vol. IV, pp. 176-198, y Aguilar Piñal, F.: La prensa española en el siglo XVIII. Diarios, revistas y pronósticos. Madrid, 1978. En cuanto a los estudios generales: Guinard, P. F.: La presse espagnole de 1737 à 1791, París, 1973; Sáiz, M. D.: Historia del periodismo en España. Vol. 1. Los orígenes. El Siglo XVIII. Madrid, 1983; Urzainqui, I.: «Un nuevo instrumento cultural: la prensa periódica», en Álvarez Barrientos, J. et al. (Eds.): La República de las Letras en la España del Siglo XVIII. Madrid, 1995, pp. 125-216; Le Guellec, M.: Presse et culture dans l'Espagne des Lumières. Madrid, 2016; y Larriba, E.: El público de la prensa en España a finales del siglo XVIII (1781-1808). Zaragoza, 2013.

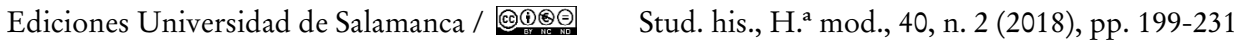


los mayoritarios de la prensa española. En las manos de sus cultores, Nifo, Clavijo o Cladera, se fue forjando la conciencia profesional del oficio de los «periodistas», «escritores públicos» o «diaristas», como una comunidad con una identidad propia en la República literaria ${ }^{2}$. En las dos últimas décadas del siglo el volumen de periódicos comenzó a ser de tal densidad que afloraron los diálogos entre sus editores. En ellos, junto al juego faccionario de censuras y acusaciones o de alabanzas y elogios, fue emergiendo el valor de la prensa como un instrumento de crítica, instrucción y ejercicio de la razón, es decir, de Ilustración ${ }^{3}$.

La prensa representó también un canal privilegiado para la diseminación de los nuevos saberes útiles. Entre ellos figuró la Economía Política o la «ciencia del comercio», tal y como fue también denominada por sus cultores del siglo XVIII. Las iniciativas de Nifo, Saura o Suárez han sido identificadas como pioneras de la prensa económica española antes de que en 1792 comenzara su andadura el primer periódico especializado: El Correo Mercantil de España y sus Indias. Sin embargo, ese tema carece de un estudio sistemático ${ }^{4}$. Este trabajo aspira a cubrir este vacío. Trata de identificar la prensa económica previa a 1792, de descubrir sus fuentes y de ubicar sus contenidos en las corrientes doctrinales de su época; por que, en suma, también en España, la prensa reflejó las formas diversas en que era pensada la Economía Política ilustrada. El corpus objeto de análisis comprende la prensa madrileña y ello debido no sólo a que fue la mayoritaria -acaparó el $70 \%$ de todos los periódicos de la centuria-, sino a que la de alcance provincial o regional afloró mayoritariamente en la última década del siglo 5 .

Al poner nuestro foco en la prensa económica española, tratamos de analizar el origen de un género diferenciado respecto de otras dos expresiones publicísticas fronterizas. La primera es la prensa comercial que, con un arraigo secular y de escala europea, ofrecía informaciones regulares a los comerciantes sobre precios,

2. Sobre la primera cuestión, vid. Checa, A.: «La terminología periodística: sus orígenes y su consolidación», Cuadernos de Ilustración al Romanticismo, 16, 2010, pp. 1- 10; acerca de la segunda, Álvarez Barrientos, J.: «El periodista en la España del siglo XVIII y la profesionalidad del escritor», Estudios de Historia Social, 51-53, 1990, pp. 29-39. La forja de la identidad periodística a través de los «espectadores» la estudia Urzainqui, I.: «Periodista-espectador en la España de las Luces. La conciencia de un género nuevo de escritura periodística», El argonauta español, 6, 2009, https://argonauta.revues.org/516.

3. Vid. Urzainqui, I.: «Diálogo entre periodistas (1737-1770)», en Maestre, J. M. et al. (Eds.): Francisco Mariano Nipho. El nacimiento de la prensa y de la crítica literaria periodística en la España del siglo XVIII. Alcañiz y Madrid, 2014, pp. 375-418.

4. Estudios parciales sobre la prensa económica se deben a Enciso, L. M.: Prensa económica del XVIII: El Correo Mercantil de España y sus Indias. Valladolid, 1958, y Domergue, L.: Jovellanos à la Société Économique des Amis du Pays de Madrid. Toulouse, 1971, pp. 201-231.

5. Enciso, L. M.: Compases finales de la cultura ilustrada en la época de Carlos IV. Madrid, 2013, pp. 336 y ss.; Larriba: op. cit., pp. 54-58, 91-100. 
tipos de interés o tipos de cambio ${ }^{6}$. La segunda son las revistas diseñadas con un marcado sentido utilitario y científico-técnico, que cultivaban el useful knowledge $\mathrm{y}$ trataban de incidir en la mejora de la agricultura y el resto de los sectores productivos ${ }^{7}$. En España, como en los países de su entorno, informaciones sobre ambas cuestiones se filtraron en los periódicos generales, incluidos los dos oficiales, el Mercurio Histórico y Político (1738) y, en particular, la Gaceta de Madrid (1697). Sin embargo, lo significativo es que en los años sesenta emergió una prensa que, sin perder su carácter polivalente, comenzó a incorporar artículos sobre Economía Política. En la mayoría de los casos se trató de simples traducciones. Por ello en este trabajo se ha privilegiado el enfoque de la circulación de las ideas, adscrito a la Historia intelectual, con el fin de precisar las fuentes que nutrieron estos primeros pasos del periodismo económico español ${ }^{8}$.

Esto último alude, en particular, a la cercana Francia, cuya sombra sobre la experiencia española fue, como veremos, cardinal ${ }^{9}$. Su marco remitía a los debates doctrinales protagonizados en los años cincuenta por el grupo de Gournay y los fisiócratas. El punto de partida fue la tradicional oeconomie, de molde aristotélico, muy presente en los primeros años del pionero Journal Oeconomique (JOE, 1751-1772). A ello sucedió una prensa presidida por el interés por la nueva ciencia del «comercio», que lideró el círculo de Gournay, auténtico catalizador de la transferencia cultural desde Gran Bretaña a Francia, a través primero de

6. Sobre los orígenes y la tipología de esa prensa, particularmene estimulada por la demanda de información que acompañó la gran transformación comercial del siglo XVIII, vid. Mccusker, J. J. y Gravesteijn, C.: The Beginnings of Commercial and Financial Journalism. Ámsterdam, 1991, pp. 21-41.

7. Mokyr, J. (The Enlightened Economy. Britain and the Industrial Revolution, 17001850. New Haven y Londres, Yale University Press, 2009, cap. 3) ha explicado muy bien la trascendencia de la difusión del conocimiento científico-técnico codificado, a través de revistas o diccionarios, como un elemento central de la agenda ilustrada, así como su importancia como plataforma de la denominada Revolución industrial.

8. Este trabajo sigue, por tanto, la senda abierta por Lluch, E. con Elpensament econòmic a Catalunya. Barcelona, 1973. Una reflexiones muy pertinentes sobre ese enfoque en Llombart, V.: «Traspassar fronteres, traduir les llums: Economia i traducció a l'Espanya del secle XVIII», en Claret, J. (Coord.), Miscellània Ernest Lluch i Martin, Barcelona, 2006, vol. II, pp. 119-134.

9. Sobre la prensa económica francesa, vid. Steiner, $\mathrm{Ph}$.: «Les grandes revues économiques de langue française au XVIIIeme siècle (1751-1776)», en Marco, L. (Ed.): Les revues françaises d'économie politique XVIIIe-XIXe siècle. París, 1996, pp. 35-78. En el caso británico, los orígenes de esa prensa son anteriores; remiten a las controversias entre The Mercator y The Bristish Merchant con ocasión de la firma del tratado franco-británico de comercio de 1713; vid. Gauci, P., The Politics of Trade: the Overseas Merchant in State and Society, 1660-1720, Oxford, 2001, cap. VI. Asimismo, se ha hecho uso de los trabajos de Sgard, J. (Ed.): Dictionnaire des journalistes (1600-1789), http://dictionnaire-journalistes.gazettes18e.fr/journaliste, $\mathrm{y}$ Dictionnaire des journaux (1600-1789), http://dictionnaire-journaux.gazettes18e.fr/journal.

Ediciones Universidad de Salamanca / 요 Stud. his., H. ${ }^{a}$ mod., 40, n. 2 (2018), pp. 199-231 
su inserción en 1754 en la dirección del $\mathrm{JOE}^{10}$ y después de la publicación del Journal de Commerce (JC, 1759-1762). Por último, se asistió a la aparición de la économie politique fisiócrata, de la mano de Éphémérides du citoyen (1767-1772) y el Journal de l'agriculture, du Commerce et des Finances (1765-1774). Este será el telón de fondo sobre el cual dio sus primeros pasos la prensa económica española.

\section{NIFO Y LA ESTAFETA DE LONDRES}

Es sabido que el inicio de la historia del periodismo económico español del siglo XVIII remite al aragonés Francisco Mariano Nifo (Alcañiz, 1719-Madrid, 1803). Su figura resulta bien conocida ${ }^{11}$, si bien todavía se ignoran los hilos gubernamentales que movieron sus proyectos periodísticos. Ello dificulta interpretar concluyentemente su sinuoso acercamiento a la emergente Economía Política. Este no fue ciertamente un tema menor de su prolífica obra periodística. En pleno periodo de efervescencia de la "primera edad de oro» de la prensa española ${ }^{12}$, ocho de sus cabeceras editadas entre 1758 y 1771 contaron con contenidos económicos. Atrás quedaba la iniciativa -efímera e inconclusa- de Graef de introducir la «ciencia del comercio» en sus Discursos Mercuriales $(1752,1756-1757)^{13}$. Tampoco tuvo una relevancia particular una primera iniciativa de Nifo: el Diario Noticioso (1758). Primer diario de la historia de España con la cabecera de «económico», se hallaba imbuido de la filosofía práctica clásica, que hacía de la «economía» una mera sección de la ética, la política y la escolástica. Sus noticias sobre «comercio civil y económico» carecían de interés: versaban sobre compraventas y geografía económica ${ }^{14}$.

Algo distinto ocurrió con La Estafeta de Londres (1762). Sus dos densos volúmenes estaban dedicados a analizar el «proceder de Inglaterra, respecto a sus costumbres, industria, artes, literatura, comercio y marina». Su contenido se hallaba

10. Todos los detalles en Orain, A.: «Le Journal Oeconomique, le cercle de Gournay et le pouvoir monarchique: quelques preuves matérielles d'un lien organique», Dix-Huitième Siècle, 45, 2013, pp. 565-583.

11. Una visión de conjunto en: Enciso, L. M.: Nipho y el periodismo español del siglo XVIII. Valladolid, 1956; y Maestre, J. M. et. al. (Eds.): Francisco Mariano Nipho. El nacimiento de la prensa y de la crítica literaria periodística en la España del siglo XVIII. Alcañiz y Madrid, 2015.

12. Entre 1760-1770 fueron publicados veintisiete periódicos, obra de una veintena de periodistas; vid. Urzainqui, «Diálogo», op. cit., pp. 386-390.

13. Para una mayor extensión, vid. Astigarraga, J.: «Oikonomia y «Comercio» en la versión española del Journal Oeconomique: los Discursos Mercuriales (1752-1756) de Graef», Cuadernos de Historia Moderna, 42 (1), 2017, pp. 39-68.

14. Lo mismo ha de afirmarse de las dos cabeceras diarias pioneras en Cataluña. Fueron editadas en Barcelona en 1762 y 1772-3 como Diario curioso por el comerciante Pedro Ángel Tarazona, siguiendo el modelo de Nifo.

Ediciones Universidad de Salamanca / 요 Stud. his., H. ${ }^{a}$ mod., 40, n. 2 (2018), pp. 199-231 
marcado por la Guerra de los Siete Años (1754-1763), con España inmersa ya en ella. Esta coyuntura explica su rasgo más revelador: su profunda anglofobia. No conocemos con exactitud las fuentes que la alimentaron. Probablemente, procedían de Francia, donde la anglofobia alcanzó su paroxismo entre 1755 y $1760^{15}$. Nifo parecía beber tanto de la panfletística que se presentaba como un Préservatif contre l'anglomanie ${ }^{16}$, como del periódico gubernamental État politique actuel de l'Angleterre ${ }^{17}$. La Estafeta respondía al mismo propósito que éste, esto es, ensanchar el campo de la guerra a la creación de «opinión»: "ce sont les gazettes, les journaux et nombre de brochures politiques qui ont servi de champ de bataille» ${ }^{18}$. Se trataba, en suma, de revertir la «inglomanía» de las elites españolas rescatando al país del «rapto político de Inglaterra». Para ello, Nifo desgranaba algunas de las tesis centrales del État politique en defensa de la superioridad de Francia respecto a Gran Bretaña.

Por encima de todas aparecían los efectos nefastos de la guerra en el futuro comercial de Gran Bretaña: de continuar el conflicto, este país habría de renunciar a subyugar la balanza europea de comercio ${ }^{19}$. Ahora bien, esta inminente decadencia no solo respondía a la coyuntura bélica: remitía también a la constitución política de Gran Bretaña. La tan admirada libertad civil de sus ciudadanos era en realidad más «engañosa» que real; además, constituía un factor contrario a la «pública tranquilidad»y al «orden de la subordinación» ${ }^{20}$. Entre las libertades más dañinas figuraban la de prensa, opinión e imprenta. Todas ellas fomentaban el tumulto y ofendían al decoro de la religión.

15. Dziembowski, E.: Un nouveau patriotisme français, 1750-1770. Oxford, 1998, pp. 59-110; y con un sentido más amplio, Grieder, J.: Anglomania in France 1740-1789. Ginebra, 1985, pp. 7 y ss.

16. De acuerdo con el elocuente título del libelo de Fougeret de Montbron, J.-L. (Menorca, 1757).

17. La iniciativa del periódico correspondió al Secretario de Asuntos extranjeros, EdmeJacques Genet, siguiendo directrices del subordinado de Choiseul, Antoine-Louis Rouillé. Fue publicado hasta que la gradual victoria británica lo dejó caduco, pero tuvo continuidad en otros proyectos efímeros (Papiers anglais, 1760; Etat actuel et politique de l'Angleterre, 1760). Sobre Genet, vid. Dziembowski, E.: «Le peuple français instruit: Edme-Jacques Genet et la traduction des écrits politiques britanniques pendant la guerre de Sept Ans», en Thomson, A. et al. (Eds.): Cultural transfers: France and Britain in the long eighteenth-century, Oxford, 2010, pp. 175-188.

18. EPA, vol. I (1757), p. V.

19. Cfr. con los numerosos pasajes del EPA en que se vincula la guerra con la futura ruina de Gran Bretaña y el auge francés, por ejemplo, vol. I (1757), pp. III y ss.; vol. II (1757), pp. $1-38$.

20. EL, vol. I, p. 41, nota. Sobre las recurrentes críticas al sistema político británico en el periódico de Rouillé, vid., por ejemplo, vol. I (1757), cartas II (43 y ss.), IV (96 y ss.) o VIII (226 y ss.). Frente a las ventajas del absolutismo monárquico, «un gouvernement mixte est de tous les gouvernements les plus tyrannique» (p. 57).

Ediciones Universidad de Salamanca / 요 Stud. his., H. ${ }^{a}$ mod., 40, n. 2 (2018), pp. 199-231 
Algo similar ocurría con las de naturaleza política. El gobierno británico era en apariencia «el más ventajoso» de todos, debido a su naturaleza mixta de «monarquía, aristocracia y democracia». Nada más lejos de la realidad, según Nifo. El sistema parlamentario era un falso sistema de contrapoderes; además, se asentaba sobre una falsa libertad en la elección de sus representantes. Ello alentaba la corrupción y un falso patriotismo basado en el sentimiento faccionario. El problema residía en que no era posible fusionar en uno «mixto» tres gobiernos tan dispares. Y la traba principal no se hallaba en el componente monárquico, cuanto en el republicano: las dos cámaras parlamentarias eran un foco de disputas permanentes y, por ello, carecían de legitimidad para obligar a cumplir las leyes. Todo se traducía en un gobierno «hermafrodita» o «anfibio», que no respondía al bien común: a diferencia de Francia y España, que lo conocían muy bien, en Gran Bretaña todo era «monstruosidad $»^{21}$. De esta manera, en plena guerra, Nifo asentaba un conjunto de argumentos que nutrirán la anglofobia española durante el resto del siglo.

Los innumerables defectos del sistema político británico arrojaban su sombra sobre la esfera económica. El problema no radicaba en el ethos de su sociedad civil. Nifo elogiaba el espíritu de iniciativa de sus habitantes o su amor por la emulación y las artes productivas; y todo ello en el marco de un conjunto de virtudes, como la liberalidad o el honor ligado a la utilidad, que justificaban las ventajas alcanzadas por Gran Bretaña en el comercio internacional. Una encarnación de esas virtudes eran la Sociedad de Dublín y otras instituciones patrióticas similares, al igual que la ejemplar política de beneficencia.

A pesar de ello, había que observar el ejemplo británico con precaución. De su esplendor económico, España debía extraer tan solo una lección práctica: los británicos fueron los primeros en identificar a la agricultura como el origen de las riquezas; por ello, fomentaron primero su agricultura, después su ganado y, solo, por último, su industria de cáñamo y $\operatorname{lino}^{22}$. Su poder económico se asentaba sobre bases tan simples como honrar al labrador, promover la industria rural y combatir la ociosidad mediante la piedad. España tenía que emular estas lecciones. Debía sencillamente tratar de recuperar su antiguo esplendor agrario: la nación fue rica y temible, «casi absoluta señora del orbe», gracias no a su poderío industrial, sino a la solidez de su agricultura. Ahora bien, esta mirada de Nifo sobre Gran Bretaña era muy precisa: él no aludía a las elogiadas leyes británicas del comercio de granos de fines del siglo XVII ni a sus admiradas reformas inspiradas en el individualismo

21. EL, vol. I, pp. XIII-XIV.

22. Todo ello a diferencia de Rouillé: a pesar de su anglofobia, éste sostenía que el poder británico se basaba en una acertada política de fomento de las manufacturas y control de las colonias; apenas aludía a su sistema agrario.

Ediciones Universidad de Salamanca / 요 Stud. his., H. ${ }^{a}$ mod., 40, n. 2 (2018), pp. 199-231 
agrario. En su obra sólo existía algún pequeño espacio para la defensa de éstas -la eliminación de los comunales- y de otros elementos de la política de desarrollo británica-los canales navegables, los caminos, la pesca o las casas parroquiales de caridad-. Era solamente el ethos del mundo agrario, y no las enormes posibilidades comerciales que éste ofrecía para aumentar la riqueza nacional e individual, lo que realmente interesaba a Nifo.

Precisamente, todas esas propuestas se hallaban subsumidas en la oeconomie. Entendida en el sentido de administración correcta, así como de gasto prudente, la oeconomie no solo marcaba absolutamente el contenido económico-político de la Estafeta, sino que se hallaba imbuida de un sentido muy tradicional. Nifo la presentaba perfectamente engarzada con las virtudes del catolicismo más depurado, las propias, a su vez, de un ecónomo, paternalista y no contaminado con las vilezas intrínsecas al comercio. La fuente de estas informaciones era sin duda el JOE. Antes de que en 1754 cayera bajo la influencia del círculo de Gournay, el periódico fue una expresión flagrante de la oeconomie. Haciendo uso de sus artículos, Nifo ensalzaba una y otra vez las bondades del trabajo rústico. Su intenso conservadurismo político no dejaba lugar a la duda. Él atribuía a los propietarios agrarios y a los párrocos el dominio de una organización sociopolítica concebida como una mera extensión de esas pulcras virtudes privadas. Éstas, además, debían servir de inspiración al hombre de Estado. Propietarios y sacerdotes debían responsabilizarse también de la dirección de las añoradas sociedades patrióticas, que debían de ocuparse solo de la agricultura, pues las manufactura y el comercio requerían de «otros sujetos».

En la Estafeta todas estas ideas se presentaban inseparablemente unidas a una crítica profunda de la sociedad basada en el comercio y la industria. La suerte de Gran Bretaña se hallaba comprometida debido a su naturaleza de sociedad eminentemente comercial. El país nunca debería haber emprendido una política de conquistas tan agresiva con el fin de domeñar nuevos mercados. Tampoco ayudaba a mejores augurios, una vez más, su sistema político. Éste favorecía la hegemonía de un nuevo ethos contrario a las virtudes del admirable ecónomo y agrónomo. Todo se había iniciado con la introducción del fausto y la vanidad, raíz de la ociosidad. A ellos siguieron otros «ídolos» de esta nociva sociedad del comercio y la industria: el lujo; la «odiosa moneda»; su circulación, que multiplicaba "por diez» los precios; y las grandes urbes: Londres convertida en el «socorro de toda Inglaterra». Nifo relacionaba todos estos males con un sistema económico basado en el gasto, en los cambios en los gustos, espoleados por el lujo: el consumo era señalado como el origen principal de todos estos males.

Al hilo de esta crítica implacable a la nueva economía del comercio y el lujo, Nifo apuntaba con el dedo al círculo de Gournay, cuya filiación anglófila, y, en menor medida, afín a las repúblicas comerciales, fue una de sus marcas características. Es 
indiscutible que él conocía bien la publicística de ese círculo ${ }^{23}$ : mencionaba o usaba las obras de Gee, O’Herguety, Davenant o Butel Dumont, el traductor del inglés Cary. No obstante, los principales destinatarios de sus acusaciones eran Hume, por su defensa de los «géneros de vanidad», y Plumard de Danguel, valedor de la prosperidad británica a pesar de desencadenar la penuria de otros países. No es casual que la Estafeta se iniciara con una crítica a Le Blanc, traductor al francés de Hume y el más anglófilo de todos los publicistas ligados a Gournay. Ahora bien, su dedo acusador se elevaba hasta señalar a la deslumbrante «ciencia del comercio». Era elogioso el afán de los británicos por difundir su «exquisita teórica» ${ }^{24}$; pero su principal defecto persistía: no solo no había resuelto los problemas centrales de la sociedad de la vanidad y el lujo -tesoros exhaustos, guerras continuas, falta de crédito-, sino que los había agravado, profundizando el proceso de decadencia de Gran Bretaña. Al combatir frontalmente al núcleo de economistas que en España -y en buena parte de Europa- estaba representando a inicios de los años sesenta la punta de lanza de la defensa de la sociedad del comercio y la industria, Nifo planteaba su oposición frontal a la dinámica modernizadora puesta en marcha por Carlos III, una de cuyas claves era precisamente la Economía Política.

\section{NIFO Y EL CORREO GENERAL DE EUROPA}

A la Estafeta, clausurada en diciembre de 1762, le siguió el Correo General de Europa. Aunque el marco de este nuevo periódico fuera el conjunto de Europa, su continuidad con el previo era indiscutible: en sus 43 cartas Nifo siguió publicitando los tópicos centrales de la oeconomie, utilizando para ello materiales del $\mathrm{JOE}^{25}$. Ahora bien, al mismo tiempo, también poseía un perfil diferenciado. Así lo prueba que incluyera, por vez primera, amplios extractos de textos de Economía Política ajenos a la inerte oeconomie. La razón de ello puede hallarse en que el Correo comenzó a publicarse tras la traumática derrota sufrida por España y la firma del Tratado de París (febrero de 1763). El fin de la guerra obligaba al país a afrontar una política de desarrollo económico. Y ello invitaba a reconsiderar

23. Vid., entre otros, Charles, L. et al (Eds.): Le cercle de Vicent de Gournay. París, 2011.

24. EL, vol. I, p. 376.

25. Del periódico francés provenía un revelador discurso de Linneo sobre las ciencias naturales como fundamento de la Economía (CGH, vol. I, carta V, pp. 129-160). También temas como la defensa del equilibrio entre las artes, la agricultura y el comercio (CGH, vol. I, Introducción, pp. XVIII y ss.; y vol. III, carta VI, pp. 345-361); o la prioridad de la economía agraria, al ser el marco natural que armonizaba las riquezas con las virtudes, de raigambre católica, del prudente ecónomo (vid., en particular, CGH, vol. I, cartas IV, V y VI; vol. III, cartas IV, V, VI y VII). 
la valía de una publicística económica que era observada por las elites ilustradas españolas como una de las razones del implacable auge británico.

De la mano de Duhamel de Monceau, Nifo abría su periódico a la «nueva agricultura» franco-británica, que estaba cambiando los modos de cultivo en las regiones más prósperas de Europa ${ }^{26}$. Con todo, como ha explicado Enciso, los autores que más le influyeron fueron Mirabeau y Bielfeld ${ }^{27}$. Nifo se planteó «traducir y adaptar» a su país el famoso y bien conocido en España L'ami des hommes (1756-1760) del primero ${ }^{28}$. Esto no llegó a consumarse, pero los amplios extractos del mismo publicados en su Correo eran muy significativos. Aludían al ambicioso plan de descentralización de la Monarquía francesa a través de la creación de «estados provinciales». Su inspiración era en origen esencialmente fiscal, pero se desbordaba hasta alcanzar una dimensión eminentemente política. Lo más relevante de la Mémoire de Mirabeau desde la perspectiva de la España post-bélica era que instigaba una reestructuración de la Monarquía sobre la base de la legitimidad de la representación como un derecho individual no sólo para la nobleza y el clero, cuanto para otros órdenes de carácter «municipal» $\mathrm{y}$ «civil» ${ }^{29}$.

El empleo por Nifo de las Institutions Politiques (1761) del cameralista prusiano Bielfeld fue más exhaustivo. En su Correo vieron la luz largos extractos sobre su proyecto de educación, de reforma del ejército y todo lo relativo a la Real Hacienda. Esto último incluía la propuesta de fundación de un órgano para estimular el desarrollo económico -el Consejo Superior de Comercio-, con competencias plenas en el fomento del comercio y la manufactura, y que sin duda podía inspirar una reforma profunda de la Junta de Comercio ${ }^{30}$. Esta apertura de Nifo a la «ciencia del comercio» venía a subrayar la utilidad que ofrecía Bielfeld,

26. Idem, vol. II, pp. 70-96, en la que se extractaban los Elemens d'agriculture (1762) de Duhamel de Monceau, libro síntesis de la «nueva» agronomía. Pese a ello subsistió la predilección de Nifo por la agronomía clásica. Buen ejemplo de ello es su compendio del tratado de Alonso de Herrera: Labranza española (1768-1775).

27. Vid. Enciso: Nipho, op. cit., pp. 105, 116.

28. CGH, vol. II, p. 315.

29. Idem, cartas VII-X. La Mémoire sur les États provinciaux (1758) apareció en el vol. II de L'Ami des hommes, ou Traité de la Population (3 vols., Avignon, 1758-1760) del Marqués de Mirabeau. Fue publicada tras su adhesión a la fisiocracia y con cambios notables respecto a una Mémoire previa de 1750; vid. Albertone, M.: «Fondements économiques de la réflexion du XVIIIe siècle autor de l'homme porteur de droits», Clio@Themis, 3, 2010, http://www. cliothemis.com/Clio-Themis-numero-3.

30. CGH, vol. I, carta III y IV (plan de educación), Consejo Superior de Comercio y política manufacturera (vol. I, cartas VIII-X), plan militar (vol. II, cartas IV-VI) y Real Hacienda (vol. IV, cartas I-V). Vid. Institutions politiques par Monsieur le Baron de Bielfeld. La Haya, 1760. Se trató de la primera traducción española de la tradición cameralista; vid. Lluch, E.: Las Españas vencidas del Siglo XVIII. Barcelona, 1999.

Ediciones Universidad de Salamanca / 요 Stud. his., H. ${ }^{a}$ mod., 40, n. 2 (2018), pp. 199-231 
con su orientación intervencionista, reglamentista y monárquica, en la remodelación de los dos elementos claves de la España derrotada en la guerra: el ejército y la Hacienda. Respecto a esta segunda, el prusiano era particularmente útil pues presentaba un plan de reforma detallado y metódico, inspirado en autores afines a Gournay -en particular, Melon y Forbonnais-. Así pues, a través de Mirabeau y Bielfeld, Nifo sumaba su Correo a la opinión mayoritaria sobre la necesidad de promover reformas socioeconómicas -nos hallamos en vísperas de la promulgación de los decretos de liberalización del comercio del grano y de las colonias- como estrategia central para robustecer la maltrecha Monarquía.

Esta nueva receptividad de Nifo hacia la Economía Política quedaba también explícita en el Diario Extranjero, un novedoso periódico publicado en 1763, en paralelo al Correo. Versaba sobre crítica bibliográfica y, por tanto, constituía el primero de la historia de España dedicado a la reseña de textos económicos. Su punto de partida era que en su país debía de activarse la traducción de este tipo de escritos. De ahí la importancia de este nuevo periódico como guía de las novedades. En él se incluían reseñas extraídas de las gacetas francesas -entre ellas, el JOE y el JC- sobre la nueva agronomía (Hirzel, Dupui-Demportes,...), la industria rural (Marcandier) y la «ciencia del comercio». La mayor atención la recababan los autores del círculo de Gournay ${ }^{31}$ : sus libros «hacen indecible falta en esta península». Muy elocuentemente, al referirse a Hume, Nifo tornaba en elogio lo que tan solo un año antes, en su Estafeta, habían sido críticas acendradas.

Al mismo tiempo, en 1763, Nifo mantenía una áspera polémica con José Clavijo (Lanzarote 1726-Madrid 1806) a cuenta de un conjunto de artículos publicados por este en El Pensador (1762-1767). Fueron los únicos sobre economía de este emblemático «espectador», que seguía la estela de Joseph Addison ${ }^{32}$. Como hará ver Nifo, esos artículos, lejos de ser originales, eran una traducción de los primeros capítulos de los Elemens de commerce (1753) del discípulo más conspicuo de Gournay, Forbonnais ${ }^{33}$. Además, su calidad era escasa, de ahí que él publicara su propia versión de estos. La polémica, basada en traducciones adicionales de nuevos fragmentos y en graves reproches sobre la calidad de las mismas, se extenderá en los números posteriores de ambos periódicos. Ahora bien, detrás de la misma se dirimían otras cuestiones de fondo. Las acusaciones cruzadas entre Clavijo y Nifo dejaban al desnudo la centralidad que el «comercio» había pasado a ocupar en los

31. DE, en particular, pp. 116 y 278. Nifo identificaba por vez primera en España a Cantillon como el autor del Essai sur la nature du commerce en général (1755).

32. Vid. Astigarraga, J.: «Forbonnais and the Discovery of the Science of Commerce in Spain (1755-1765)», History of European Ideas, 2014, 40-8, pp. 1087-1107, pp. 1093-1095. Esos artículos volverán a ser publicados hacia 1780, en la selección de El Pensador realizada por el barcelonés Pedro Ángel Tarazona: EPM, vol. III, pensamiento XXXVIII, pp. 247 y ss.

33. EHJ, 1-4, pp. 37-49. 
círculos de sociabilidad, no solo entre las elites cortesanas, sino también entre un «público» más general: ese tema era, en palabras de Clavijo, de «mucha utilidad para el público, que por lo general oye hablar de comercio en términos muy vagos sin poder adelantar ni aun formarse ideas justas de un ramo tan importante, por falta de principios» ${ }^{34}$. De esta manera, el «comercio» se había convertido en un objeto preciado de emulación y promoción pública. Su polémica con Nifo dirimía, en algún sentido, cómo podía utilizarse la prensa con esa finalidad promocional y quién se beneficiaba de ello. Y los Elemens de Forbonnais resultaban una coartada perfecta dada la buena acogida que este libro estaba teniendo esos años en España.

Aun resta por considerar otras dos iniciativas de Nifo. En 1769 obtuvo el apoyo del Consejo de Castilla y la Junta de Comercio para elaborar una geografía económica de la Monarquía peninsular, a partir de un interrogatorio completo -sobre economía, población, policía, etc..$^{35}$-, que fue remitido a los intendentes, corregidores y otras autoridades locales. El proyecto trataba de solventar la reiterada queja sobre la falta de información factual acerca de la economía española. Su objetivo era realizar una especie de «anatomía» de la Monarquía, con un sentido más descriptivo que cuantitativo o aritmético-político. Sus resultados se ofrecieron comprimidos en dos publicaciones periódicas, el Correo General de España (1770) y la Descripción natural, geográfica, y económica de todos los pueblos de España (1771). Ambas fueron en realidad publicaciones híbridas: combinaban las noticias enviadas desde las localidades con órdenes reales, instrucciones sobre oficios y discursos ${ }^{36}$. Ahora bien, no por prolijas evitaron el fracaso del proyecto. Nifo trató, con muy poco éxito, de adelantar el esfuerzo estadístico que liderará a finales de siglo la Junta de Comercio, una vez creada la oficina de la Balanza de Pagos. Su proyecto se frustró por la falta de respuesta de las autoridades y de financiación. En marzo de 1771, después de constatar que su interrogatorio apenas había sido distribuido, por ser muy gravoso para las autoridades realizar copias, solicitó nueva financiación, que el Consejo le negón ${ }^{37}$.

Esta cuestión obliga a volver a considerar la duda acerca de la autonomía real de las empresas periodísticas de Nifo. Sus elocuentes quiebros durante la década en la que lideró la prensa española entre la oeconomie y la «ciencia del comercio» parecen responder a exigencias de unas autoridades precisas, algo sobre lo que se sabe realmente poco. Quizás también, por esta misma razón, como veremos, Nifo

34. EP, vol. III, pensamiento $\mathrm{XL}$, sin paginar.

35. CGE, vol. I, pp. XIX y ss. El interrogatorio se hallaba preparado desde 1766 (Fundación Universitaria Española, Archivo Campomanes, leg. 24-18).

36. Guinard: op. cit., pp. 132-133. El único reseñable es el de Manuel Martínez de Irujo (CGE, vol. II, pp. 341-377).

37. Archivo Histórico Nacional (en adelante AHN), Consejos, leg. 5 531-32. 
JESÚS ASTIGARRAGA

PRENSA ECONÓMICA DE LA ILUSTRACIÓN ESPAÑOLA (1758-1792)

no desaparecerá de la escena del periodismo económico español en las décadas posteriores.

\section{LA MISCELÄNEA POLÍTICA DE BARBERI}

A finales de agosto de 1763, en el epicentro de la frenética actividad publicística de Nifo, vio la luz la primera carta de las cuatro que compondrán la Miscelánea política del abogado Mateo Antonio Barberi (Cádiz, 1723- ¿ ?). Éste las redactó en Cádiz, su ciudad natal, inmerso en su denso tejido mercantilis. Su Miscelánea se abría con un extenso elogio -el más elocuente de la escena periodista de su época- de la «fermentación» de los escritos económicos ${ }^{39}$. A ella contribuía particularmente la traducción. Barberi la consideraba un «importantísimo» acto de servicio patriótico a la nación; por ello eximía a los traductores de la acusación de plagiarios. Junto a la defensa del clima de liberalización cultural abierto con Carlos III, no hay duda de que Barberi intuía que la traducción se había convertido en una poderosa palanca de promoción social, que él mismo deseaba utilizar: para 1763, cuando comenzó a escribir su Miscelánea, ya había solicitado la licencia para realizar dos traducciones ${ }^{40}$.

La obra reflejaba perfectamente la doble afiliación franco-británica de la publicística que Barberi denominaba precisamente la «ciencia del comercio» y que, a diferencia de Nifo, él aceptaba sin ambages. Aunque personificara su origen en Locke y Newton ${ }^{41}$, fue desarrollada bajo el influjo del círculo de Gournay: Barberi mencionaba a Plumard de Dangeul y Forbonnais, así como diversas traducciones realizadas en su seno (King, Child y Culpeper). No obstante, en la redacción de su Miscelánea dispuso de una fuente privilegiada: el JC. Este fue un periódico mensual, editado en plena Guerra de los Siete Años, en Bruselas, a la sombra del poder austríaco, por el exiliado francés Jacques Accarias de Serionne ${ }^{42}$. Sus contenidos respondían a tres tópicos: la defensa del «patriotismo de comercio» y sus manifestaciones en la proliferación de libros y sociedades económicas; su afiliación antifisiócrata y afín al núcleo de Gournay; y su naturaleza de instrumento

38. Sobre Barberi, vid. Usoz, J.: «Mateo Antonio Barberi: el ideario de la Junta General de Comercio en Aragón», Cuadernos Aragoneses de Economía, 8 (2), 1998, pp. 501-523. La MP fue el primero de sus escritos.

39. MP, carta II, pp. 25-26.

40. AHN, Consejos, leg. 50659.

41. MP, carta I, p. 16. Barberi sigue el JC, vol. I, pp. I-XVIII.

42. Hasquin, H.: «Jacques Accarias de Serionne, économiste et publiciste français au service des Pays-Bas Autrichiens", en Mortier, R. et al (Eds.): Études sur le XVIIIe siécle. Bruselas, 1974, pp. 159-170. Barberi hace un uso intensivo del Catalogue raisonné de libros de Economía incluido en el primer volumen del periódico (pp. 23-51).

Ediciones Universidad de Salamanca / 요 Stud. his., H. ${ }^{a}$ mod., 40, n. 2 (2018), pp. 199-231 
de creación de «opinión» antibritánica. A España el JC llegó muy pronto, de la mano de poderosos comerciantes, como Iranda o Heros, además de Barberi. De hecho, en 1763 este ya había traducido al castellano su primer volumen, «con varias reflexiones»; no obstante, el Consejo de Castilla, antes de otorgar la licencia de impresión, lo envió a la Junta de Comercio, que pudo interrumpir su publicación ${ }^{43}$.

La Miscelánea era un «discurso acomodado al estilo práctico del comercio» ${ }^{44}$. Se vertebraba alrededor de la trascendencia socioeconómica de éste. El problema central de España residía precisamente en la penuria de su comercio. A ello se debía la inacción de su agricultura y el subdesarrollo de su manufactura. Ello inundaba la Monarquía de géneros extranjeros, algo letal para la economía nacional. La solución no era meramente técnica, sino que, en línea con el JC, exigía poner todo el aparato de la Monarquía al servicio de los mecanismos propios de las opulentas sociedades comerciales. Bien lejos del primer Nifo, Barberi se mostraba favorable a activar la circulación del dinero; al consumo, si bien regulado a través de leyes suntuarias para evitar la excesiva importación de bienes y la descapitalización de los fabricantes nacionales; y a fundar una compañía general dedicada a financiar actividades comerciales. Su apología de la rehabilitación social del comercio partía de su defensa de la «nobleza comerciante» de Coyer -otro miembro del círculo de Gournay- y de la educación en la «ciencia del comercio»-que debía incluir el «sistema político de las naciones»- entre los jóvenes, los políticos y los altos funcionarios. Nos hallamos, en suma, ante la mutación de la idea tradicional de la virtud social. Ésta debería remodelarse para dar entrada en la cúspide de la pirámide social a los comerciantes. Como la nobleza, estos ejercían una actividad pacífica, moduladora de las costumbres sociales y necesaria para el bien público; por ello, eran «verdaderos ciudadanos», que «sirven al Estado y la patria, manteniendo muchas familias, que desgraciadamente se abandonarían ${ }^{45}$.

Muy afín a estas reflexiones resultaba otro tema central de la Miscelánea: la legitimidad del cobro del tipo de interés en las operaciones de préstamo. Esto era propio no solo de las culturas calvinista o luterana, sino también de la católica, y resultaba esencial para la financiación de las compañías comerciales y fabriles. Ello obligaba a reformar las leyes vigentes sobre la usura. Aunque en sus argumentos se perfila su imbricación en los negocios gaditanos, Barberi escribía al calor de la polémica surgida en Madrid en torno al pago de intereses a los préstamos concedidos

43. MP, carta I, p. 8; AHN, Consejos, leg. 50 659. En las posteriores Cartas político-instructivas sobre varios puntos de la felicidad pública (Madrid, 1770), los artículos de Serionne volvían a guiar a Barberi en sus referencias a los libros de Mirabeau o Patullo, siempre con el telón de fondo de la preocupación por la inactividad de la nobleza y la conveniencia de implicarla en el comercio y en la mejora de la agricultura.

44. MP, carta IV, p. 113.

45. Idem, p. 153. 
a los Cinco Gremios Mayores, poco antes del Decreto de 1764, que reconoció la licitud de esos pagos. Estamos ante la justificación escolástica en la que se apela a las sagradas escrituras e intervienen los conceptos de «lucro cesante» $\mathrm{y}$ «daño emergente». Su fundamentación recordaba concretamente al contrato trino ${ }^{46}$. No obstante, junto a todo ello, Barberi conectaba otra vez con el reformismo del grupo de Gournay al defender que la rebaja del tipo de interés era una condición insoslayable para estimular el crecimiento económico español ${ }^{47}$.

Ahora bien, más allá de sus apelaciones a la ortodoxia católica, la posición de Barberi remitía a la preeminencia que en toda sociedad política tenía el Derecho público y de gentes ${ }^{48}$. Así, volvía a conectar con el JC, que consideraba la «ciencia del comercio» una rama del Derecho Público. Su punto de partida era la idea de la sociabilidad natural del comercio, fundamento de los principios de seguridad, protección y mutuo socorro que ofrecía a los individuos la sociedad civil, una vez consumado el contrato social. El comercio se erigía así en un vínculo esencial de todas las sociedades políticas, aunque éstas dispusieran de sistemas jurídicos diferenciados. A su vez, los fundamentos del Derecho de gentes jerarquizaban la sociedad política sobre el principio de soberanía, cuyas determinaciones eran «leyes obligatorias». De esta manera, dado que los contratos comerciales, ahora de licitud dudosa, eran de común utilidad, no existía razón para proscribirlos. El tema no admitía lugar a la disputa, a menos que llegara a cuestionarse la propia «sociedad general de los hombres», fundamentada en el giro del dinero y en su trascendencia en la actividad comercial. La conformación de la soberanía era así esencial para la «ciencia del comercio», cuyo sustrato era esencialmente político. En un pasaje de sus cartas, Barberi copiaba el argumento de Forbonnais acerca de que los intereses privados del comerciante y los públicos no tenían porqué coincidir. La tarea del legislador consistía en armonizarlos para que redundasen en beneficio de los segundos ${ }^{49}$. Esta apología del comercio por parte del gaditano hubo de ser bien recibida en los sectores oficiales. Poco después de publicar su Miscelánea, alcanzará diversos cargos en la administración borbónica y, más en particular, en la Junta de Comercio, primero como director de la Real Fábrica de Zaragoza y después, entre 1769 y 1772, como Archivero.

46. Usoz: op. cit., p. 514.

47. Barberi cita tácitamente la traducción de Gournay y Butel-Dumont de Child, J.: Traités sur le commerce, Ámsterdam y París, 1754; en sus pp. 441-478 figuraba el Traité contre l'usure (1621) de Th. Culpeper. Como se refiere en aquel, Barberi destaca las ventajas de la economía holandesa sobre la británica por operar con bajos tipos de interés.

48. MP, carta I, p. 12. Barberi elogia diversas obras españolas enraizadas en esa tradición jurídica, como las de Abreu y, en particular, Pérez Valiente, quien «empezó a echar los primeros cimientos a un edificio que no es poco difícil de concluir»; no obstante, sus fuentes parecen ser Jean Domat y Francisco Schmier.

49. Idem, carta II, pp. 25-26. 


\section{EL SEMANARIO ECONÓMICO DE SAURA}

Las iniciativas de Nifo y Barberi fueron proseguidas por el Semanario Económico (1765-1767). Su editor fue Juan Pedro de Saura ${ }^{50}$. Las noticias sobre el «comercio» aparecían en él bajo la forma de breves artículos o reseñas. Los mayoritarios eran sobre artes aplicadas, que incluían las agronómicas, si bien la «nueva» agronomía ocupaba en ellas un espacio reducido. Precisamente, un texto tan tradicional como el Dictionnaire oeconomique (1709) de Chomel fue una de las vías privilegiadas de las noticias económicas del Semanario, en general, más afines a la geografía comercial que a la teoría del «comercio» ${ }^{51}$.

No obstante, esas noticias económicas bebían también de otras fuentes, como las Mémoires de Trévoux, el Journal des Savants, el JOE o el JC. Esta última fue sin duda muy empleada. Se hizo presente ya en agosto de 1765, en el seno de una nueva rúbrica de «Noticias literarias y de comercio». En ella se mencionaba el «Diario de comercio de Bruselas», en el que, según Saura, se ventilaban «todos los principios de la opulencia de las naciones»: en él se exponían los principios de «un siglo que solo piensa en aprovecharse de todas las ventajas del comercio» ${ }^{52}$. Saura anunciaba su intención de introducir en números posteriores artículos de esta «excelente» obra. En efecto, dos meses después extractaba la «Introducción» de Serionne para el JC. En ella se defendía que en ese siglo la «política hace al comercio la basa de los estados» y lo presentaba como un diario dedicado «solo» al comercio, cuyo contenido alcanzaba no solo «la mecánica del comercio sino también su administración, de suerte que se puede contemplar como un manual de los comerciantes y código de legisladores» ${ }^{53}$.

Saura comenzó por glosar, en siete entregas, una extensa memoria de Serionne sobre el comercio de Portugal ${ }^{54}$. Su elección se debía a que el patrón comercial de Portugal era muy similar al español: el exceso de metales preciosos procedentes de Brasil había devastado los sectores productivos de la metrópoli portuguesa. Su análisis se basaba en Cantillon, cuyo prestigioso Essai había sido difundido en 1755 por el círculo de Gournay. Saura recogía sus ideas sobre el efecto inflacionista de un país propietario de minas, a través del mecanismo del gasto, así como la incompatibilidad entre el aumento de la masa monetaria y el desarrollo manufacturero. También aludía a las ideas de Serionne, inspiradas ahora en Forbonnais,

50. Un análisis en profundidad en Ocampo, J.: «El Semanario Económico (1765-1767): a la Ilustración por la utilidad», El Argonauta español, 10, 2013, http://argonauta.revues.org/1926.

51. SE (Saura), vol. II, pp. 14-16, 23-24, 30-32, 39-40, 47-48, 55-56, 64 y 71-72.

52. Idem, vol. I, p. 227.

53. Idem, p. 228; cfr. JC, vol. I, pp. I-XVIII.

54. Idem, pp. 127-128, 135-136, 242-244, 251-252, 239-240, 247-248 y 256; cfr. JC, desde septiembre de 1759 a abril de 1760 .

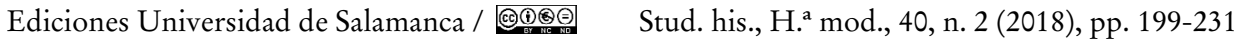


acerca de la mala administración de Portugal: el privilegio exclusivo cedido a Gran Bretaña en 1703 en el Tratado de Methuen era la causa de su servidumbre comercial. La solución pasaba por abrir el comercio portugués al libre comercio internacional. Y dada su dificultad para competir con éxito en el mercado de las manufacturas, debía de especializarse en la oferta de servicios de navegación y de bienes agrarios y coloniales. Conclusiones similares obtenía Serionne en otra memoria sobre España. A pesar de ser crítico con su contenido, Saura anunció su publicación ${ }^{55}$. Ello finalmente no sucedió. La razón puede hallarse en que ya había sido «pirateada» en 1761 en unas extensas Reflexiones del comerciante Simón de Aragorri ${ }^{56}$. Y algo similar ocurrió con otras informaciones tomadas del JC: Saura publicó tres breves reseñas de libros de Child, Butel-Dumont y Forbonnais, pero sin ahondar en su contenido.

En otras noticias del Semanario se combinaban materiales del JC y el JOE. En los primeros meses de 1767 publicaba un extenso resumen, en diez entregas, de Le droit publique de l'Europe (1740) de Mably ${ }^{57}$. Su justificación se hallaba en el final reciente de la Guerra de los Siete Años. Como Mably, Saura sostenía que cada país debía crear un «sistema fijo de política», acorde con su geografía y su gobierno. Ese sistema debía ser respetuoso con el Derecho Público, ciencia destinada a «hacer los pueblos felices y enriquecerlos con los tesoros de la paz» ${ }^{58}$. El comercio estaba destinado a jugar un papel destacado en todo ello. Emergía como un poderoso agente pacificador y estimulador de los nuevos equilibrios internacionales, hasta el punto de que Mably, según Saura, parecía haber «confundido el arte de negociar con el arte de hacer florecer el comercio» ${ }^{59}$.

Esta misma idea de que la balanza de «poder» se confundía con la de «comercio» servía de guía a Saura para reclamar que la nobleza se implicara en el comercio. El JC y otras publicaciones bien conocidas en España, como el JOE, las Mémoires de Trévoux o el Journal Enciclopédique, se hallaban detrás del amplio resumen que su Semanario incluyó en 1766, en siete entregas, de La noblesse commerçante (1755) de Coyer $^{60}$. Se trató de la primera versión de este libro, destinado a tener un enorme éxito en la Ilustración española. Saura glosaba sus ideas centrales. Dado que el comercio era la fuente de las riquezas y el poder nacional, resultaba imprescindible abrirlo a la nobleza. Más aún cuando era la única vía de enriquecimiento

55. SE (Saura), vol. I, p. 256.

56. Vid. Astigarraga, J.: «Un nuevo sistema económico para la Monarquía española. Las Reflexiones sobre el estado actual del comercio de España (1761) de Simón de Aragorri», Revista de Historia Industrial, 52, 2013, pp. 13-44.

57. SE (Saura), vol. III, pp. 32, 40, 47-48, 55-56, 63-64, 71-72, 79-80, 88, 94-96 y 103-104.

58. Idem, p. 32.

59. Idem, p. 56.

60. Idem, pp. 263-264, 271-272, 278-280, 287-288, 203-204, 312 у 320. 
para esos sectores de la misma ociosos o empobrecidos. En la medida en que ellos prosperaran, lo haría toda la nación. Saura subrayaba, sin duda con la vista puesta en su país, que una razón notable del subdesarrollo de Francia respecto a Gran Bretaña u Holanda se debía precisamente a la «inacción» de su nobleza.

Nuevos tópicos propios de la «ciencia del comercio» reaparecían en unas extensas «Reflexiones sobre la balanza de comercio» que el Semanario publicó en 1765, en cuatro entregas. Su primera finalidad era mostrar que los registros de aduanas eran, a diferencia del saldo monetario, un criterio equívoco para cuantificar la balanza de comercio. A ello se unía una amplia reflexión sobre el modo aprovechar las colonias para mejorar el saldo de esa balanza. El modelo más útil para España era el francés. Éste venía a ratificar que el fomento de nuevas explotaciones agrarias en las colonias, repobladas con indigentes dotados de tierras y esclavos, había propiciado su dominio del comercio de azúcar; y lo mismo comenzaba a suceder con el del tabaco. La protección del gobierno era por tanto la condición previa para operar con éxito en el comercio internacional. Aunque no se aludiera a ello, esta digresión parecía tener como trasfondo el reglamento de comercio libre con las colonias de 1765. Además, era menos original de lo que Saura podía pretender. Se trataba de un resumen de The trade and navigation of Great Britain (1729) del británico Gee, ya traducido al castellano en 1753 y reseñado dos años después en el JOE ${ }^{61}$. Esta fuente fue sin duda la elegida por Saura para introducir un amplio resumen del escrito de Hume Of National Characters (1748), la primera traducción del escocés en España: el JOE había incluido en 1755 amplios fragmentos de ese escrito $^{62}$. De esta manera, en suma, Saura incorporaba a su Semanario algunos de los tópicos más característicos de la emergente Economía Política, siguiendo a autores tan relevantes como Mably, Hume, Coyer, Gee o Serionne, así como a dos publicaciones tan representativas como el JOE y el JC.

$\mathrm{Su}$ iniciativa pone fin a la primera etapa de la prensa económica española. Entre 1758 y 1771 alrededor de once periódicos habían comenzado a desbrozar este camino. Lógicamente, esta incipiente prensa económica no fue ajena a los problemas padecidos por el resto de las cabeceras del período: se trató, en suma, de proyectos efímeros, titubeantes, carentes de financiación y mal adaptados al público, ese «personaje de la mayor autoridad» al que, según Nifo, todos decían servir ${ }^{63}$. No por ello esos años carecen de relevancia. En primer lugar, debido a que, aunque no poseamos informaciones precisas sobre los lectores de esa prensa,

61. JOE, abril de 1755, pp. 168 y ss.; mayo de 1755, pp. 372 y ss.; vid., asimismo, la traducción española de Gee, J., obra de Noboa, B. J.: Consideraciones sobre el comercio y la navegación de la Gran Bretaña. Madrid, 1753, pp. 199-222 y 223 y ss.

62. SE (Saura), vol. III, pp. 291-292 y 347-348. En el JOE los extractos de este capítulo de los Essais de Hume vieron la luz a partir de julio de 1755 (pp. 726 y ss.).

63. CGH, vol. I, p. VI. 
como hemos visto, las iniciativas de Nifo, Barberi y Saura parecen instigadas por una misma causa: la Economía Política había pasado a ser un centro de interés entre las elites ilustradas, a las que se destinaban sus periódicos, así como un mecanismo de promoción social en las escalas del poder. No menos ilustrativas resultan, en segundo lugar, las fuentes de que se nutre esta primera apertura de la prensa española hacia la publicística económica europea. No debe de olvidarse que esa prensa maduraba en un contexto de ausencia de libertad de expresión y sometida a una estricta doble censura, civil e inquisitorial, de ahí que no se pueda descartar el ejercicio de la autocensura ${ }^{64}$. En este sentido, resulta muy expresivo comprobar que, al mismo tiempo que apenas existen pruebas de influencia de la prensa fisiócrata, Barberi y Saura, utilizando profusamente el JC, situaron sus cabeceras en la estela de la Ilustración «oficial», dado que los autores del influyente círculo de Gournay, y en menor medida los cameralistas, estaban conformando en esos años la mainstream de la Ilustración económica española ${ }^{65}$.

\section{EL SEMANARIO DE CUBIÉ Y LAS MEMORIAS DE SUÁREZ}

A diferencia de la prensa general, que hubo de esperar a 1781 para dar inicio a su consagración como un género maduro ${ }^{66}$, la de contenido económico apenas padeció la crisis de los años setenta. Solo pasaron media docena de años desde la clausura en 1771 del último periódico de Nifo hasta la aparición en 1777 de dos nuevas iniciativas, de la mano de Cubié y Suárez. Esos años además no fueron de silencio. Los dos periódicos oficiales, la Gaceta de Madrid y el Mercurio Histórico, fueron entonces un poderoso canal en la diseminación, no sólo de informaciones sobre el comercio o las técnicas productivas, cuanto de normas legislativas en materia económica (comercio de granos o gremios), en particular las relativas a la Hacienda pública francesa durante los convulsos años de Turgot y Necker ${ }^{67}$. En cualquier caso, esta nueva etapa, que se inicia en 1777 y tendrá su fin en 1792, año de la publicación de El Correo Mercantil, se benefició de las mejoras que conoció la prensa en su conjunto: mejora de la distribución, aumento del

64. Le Guellec: op. cit., pp. 21-24.

65. Aludimos a Forbonnais, Dangeul o Herbert. La vía privilegiafa fue la traducción, vid. Llombart, V.: «Traducciones españolas de economía política (1700-1812): catálogo bibliográfico y una nueva perspectiva», CROMOHS, n 9, 2004.

66. Guinard: op. cit., pp. 219-220.

67. Los detalles figuran en Astigarraga, J.: «La traduction au service de la Politique. Le succès de Jacques Necker dans les Lumières espagnoles», Annales Historiques de la Révolution Française, 364, 2011, pp. 3-27, y «Les traductions espagnoles des normes législatives et des écrits économiques de Turgot (1774-1791)», Annales Historiques de la Révolution Française, 384, 2016, pp. 27-51. 
público potencial, reducción de costes e introducción generalizada del sistema de suscripción; detrás de ellas se encuentran las claves del inicio de la «edad de oro» definitiva de la prensa española ${ }^{68}$. En cuanto a la económica, maduró además con un rasgo específico: fue tutelada por una Ilustración «oficial» que comprendió sin ambages su importancia como instrumento de instrucción, así como para ganar adeptos para las reformas en desarrollo. En 1775 Campomanes establecía con claridad cuál debía ser la nueva pauta:

«las gacetas de comercio, los diarios económicos, y otras obras periódicas de esta naturaleza, son los escritos que han ilustrado a nuestros vecinos. Este mismo efecto producirán en España, luego que se haga de moda en los estrados su lectura y cálculo, en lugar de las bagatelas que suelen tratarse en ellos» ${ }^{69}$.

Su juicio apelaba sin duda al conjunto de los sectores ilustrados. La promoción de los conocimientos económico-políticos se insertaba en un programa más amplio, en el que la prensa, las traducciones y las sociedades económicas debían convertirse en auténticas incubadoras del «espacio» y la «opinión» públicos. Precisamente, la proliferación de sociedades económicas a partir de 1776 generó efectos multiplicadores sobre la prensa. Aunque, como explica Larriba, fueran menores de los esperados ${ }^{70}$, la prensa no sólo fue un canal para la divulgación de las actividades de esas sociedades -así sucedió con la Gaceta de Madrid y con numerosas cabeceras de provincias-, sino que propició la creación de un mercado -ya más que potencial- de oferta y demanda de conocimientos económicos: al tiempo que estos era requeridos por los amigos del país, esas sociedades permitían complementar la publicación de traducciones con la producción de textos nacionales. La prensa se erigía así en un instrumento de apoyo a las memorias y los debates internos de las sociedades económicas: a finales de los ochenta Manuel de Aguirre proponía en El Correo de los ciegos utilizar la red de éstas para crear unas «juntas de civilización» destinadas a comentar la prensa y otros papeles públicos. Esas sociedades promovieron también sus propios periódicos económicos. El primero lo fundó la Sociedad Mallorquina. De alcance insular, su contenido era el propio de la prensa comercial ${ }^{11}$.

68. Le Guellec: op. cit., pp. 24-28, y Larriba: El público, op. cit., pp. 20-22.

69. Apéndice a la Educación Popular. vol. I, Madrid, 1775, p. XXII.. Sempere, J. abundó en quejas similares: op. cit., p. 178.

70. Larriba, E.: «Las Reales Sociedades Económicas de Amigos del País y la prensa de la Ilustración», en Aubert, P. et al. (Eds.): Les élites et la presse en Espagne et en Amerique Latine. Des Lumiéres à la seconde guerre mondiale. Madrid, 2004, pp. 33-49.

71. Titulado expresivamente Noticia periódica de los precios corrientes de la semana, muy poco después de publicado pasó a ser denominado Palma de Mallorca y a partir de 1795, cuando amplió sus contenidos e introdujo el sistema de suscripción, Semanario Económico, Instructivo y Comercial de Palma de Mallorca; vid. Larriba, El público, op. cit., pp. 57-58.

Ediciones Universidad de Salamanca / 요 Stud. his., H. ${ }^{a}$ mod., 40, n. 2 (2018), pp. 199-231 
Detrás de todo ello se hallaba, por tanto, la conformación de un «nuevo público» interesado en estos peculiares «papeles económicos», que, como explicaba Jovellanos, se leen en «el café, el tocador de sobremesa o la tertulia» y que, por ello, debían de aunar la pulcritud de la «buena pluma» con el rigor de sus contenidos $^{72}$. Por ello, las críticas sobre la penosa situación de la prensa económica -mediados los setenta no se hallaba activa ninguna cabecera- se solaparon con la exaltación de la misma como un poderoso vector de la Ilustración entre autores como Jovellanos, Sempere, Cabarrús o Foronda. La prensa, además de moldear la opinión pública, constituía una vía rápida y de bajo coste para especializar los conocimientos y divulgarlos entre públicos amplios: esto es, como precisaba Guevara Vasconcelos, era como un "prontuario» de cosas útiles, que excitaba la «curiosidad, la novedad y el gusto» y al que se recurría para «tentar algunas ideas que se quieren reducir a la práctica» ${ }^{73}$; o, en palabras de Sempere, "para extender más rápida y generalmente la Ilustración a todas clases de ciudadanos» ${ }^{74}$. La famosa Orden de 19 de mayo de 1785 de Floridablanca, con carácter de primera ley de prensa como un desiderátum de la política oficial, se explica mejor en este contexto de efervescencia, vehementemente expresado también en una intensa campaña liderada por los ilustrados tardios, desde Foronda y Arroyal hasta Cabarrús, a favor, en palabras de este último, de la «libertad de las opiniones». Esa Orden no supuso ciertamente la supresión de la censura, pero amplió notablemente el margen de maniobra de la prensa ${ }^{75}$.

La fundación de la Sociedad Matritense en 1775 marcó, por todo ello, un turning point en la historia de la prensa económica española. La razón es que cobijó intentos ininterrumpidos de creación de nuevas gacetas. La iniciativa era virtualmente oficial dado que el Consejo de Castilla cedió a la Sociedad las labores de censura. En junio de 1777 Juan Cubié, bibliotecario real, anunciaba a la Matritense su deseo de proseguir editando el Semanario de Saura. Su iniciativa no tardó en pasar la censura de la Sociedad: la principal prevención del censor,

72. «Dictamen sobre la oportunidad de publicar una gaceta económica» (1786), en Jovellanos, G. M.: Obras completas. Tomo X: escritos económicos, Llombart, V. et. al. (Eds.), Gijón, 2008, p. 649.

73. AHN, Consejos, leg. 5 540-23.

74. Sempere: op. cit., p. 176.

75. Las licencias de impresión de las publicaciones que no excedieran de 4 a 6 cuadernos, que eran las mayoritarias, quedaban bajo la competencia del juez de imprentas; vid., Le Guellec: op. cit., pp. 21-24 y Larriba, E.: «Inquisición y prensa periódica en la segunda mitad del siglo XVIII», en Cuadernos de Ilustración y Romanticismo, 13, 2005, p. 78. Sobre la campaña coetánea mencionada, vid. Larriba, E.: «Las aspiraciones a la libertad de imprenta en la segunda mitad del siglo XVIII», en Larriba, E. et. al. (Eds.): El nacimiento de la libertad de imprenta. Madrid, 2012, pp. 19-41. 
Guevara Vasconcelos, era evitar la excesiva fragmentación de los artículos ${ }^{76}$. La idea de Cubié era «seguir el método» de Saura ${ }^{77}$. Ello fue así en términos formales, pero no de contenido. El nuevo Semanario no incluyó noticias sobre el comercio, tan solo sobre artes y oficios, y economía rústica; eso sí, el espacio para la «nueva agronomía» era ahora más amplio. Cubié publicó, con un objetivo didáctico, diversos artículos sobre los nuevos instrumentos agrarios (arados y sembraderas), la industria rural (el cáñamo y el lino) y el novedoso método de cultivo de Tull-Duhamel, del cual se ofrecía en el otoño de 1777 un extenso resumen en el Semanario. Buena parte de sus noticias provenían del JOE y, marginalmente, de textos clásicos sobre economía rústica (Liger). Esta nueva versión del Semanario se configuraba como una extensión del dominio de la oeconomia, con un carácter además anacrónico: muchos de sus materiales poseían más de un cuarto de siglo. Su principal particularidad era que poseía vasos comunicantes con la Matritense: su primer destinatario eran sin duda la Comisión de Agricultura, para la que la «nueva agronomía» constituyó el centro de su atención desde su creación en 1776.

En cualquier caso, lo más probable es que el Semanario de Cubié no convenciera plenamente a la Matritense. Fernández de Moratín, el nuevo responsable de la censura, le hizo saber pronto que la Sociedad no se responsabilizaba de la veracidad de sus contenidos ${ }^{78}$. Su publicación fue además interrumpida temporalmente por la propia Matritense a las pocas semanas de iniciada, debido a que en octubre de 1777 el socio Miguel Jerónimo Suárez y Núñez le había adelantado su deseo de publicar unas «Noticias semanales sobre agricultura, industria y comercio». El Consejo de Castilla estableció que esta nueva solicitud no debía anular la licencia de la que disfrutaba Cubié, pero, sin duda, hubo de herir de muerte su Semanario: este solo se extendió durante veintisiete números, entre octubre de 1777 y junio de 1778. También abortó una propuesta posterior de Pedro Dabout, otro miembro de la Matritense, de publicar una gaceta económica, semanal o mensual, que diera continuidad al periódico de Cubié ${ }^{79}$.

En 1778 veía la luz el primer número de las Memorias de Suárez (Madrid 1733-Madrid, 1791 $)^{80}$. En su rápida aprobación por la Matritense hubo de influir el brillante perfil de su editor. Suárez venía avalado por su membresía en prestigiosas instituciones patrióticas - como la Bascongada o la Academia Sevillana de Buenas Letras-y por una trayectoria intachable como traductor de tratados sobre ciencias y artes aplicadas. Esa trayectoria había sido reconocida por la Junta de Comercio,

76. AHN, Consejos, leg. 5 540-23. Su informe era del 20 de junio de 1777.

77. SE (Cubié), vol. IV, p. 8.

78.AHN, Consejos, leg. 5 540-23. Su informe era del 18 de octubre de 1777.

79. Domergue: op. cit., pp. 203-204.

80. Sobre Suárez, vid. Aguilar Piñal, F.: «Un traductor de la ciencia ilustrada: Suárez y Núñez», Cuadernos Dieciochistas, 7, 2006, pp. 87-112. 
que en 1772 le había nombrado su Archivero, y después por la propia Matritense, de la que fue uno de sus primeros miembros en su Clase de Artes, además de su Secretario entre 1776 y 1781. En el seno de la Sociedad, Suárez dispuso además del mejor de los avales posibles: en 1781 Campomanes alabó la calidad de sus traducciones ${ }^{81}$.

Las Memorias respondieron a una iniciativa realizada «por orden» de la Junta de Comercio, pero financiada por el propio Suárez. Se trató de una iniciativa ejemplar, debido tanto a la cantidad y la calidad de sus contenidos como a su dilatación en el tiempo. Su publicación requirió de una notable planificación. En numerosas ocasiones, las Memorias publicaron tratados muy extensos, que Suárez hubo de fragmentar para cumplir con sus entregas semanales. Finalmente, comprendieron casi un centenar y medio de memorias, que quedaron reunidas en doce volúmenes, publicados entre 1778 y 1791. Esas memorias eran traducciones referidas a los dominios evocados en el título de la publicación -la «agricultura, comercio, industria, economía, química, botánica, historia natural, etc.»-, con una particular atención a las ciencias (química) y artes aplicadas (la agronomía y las técnicas del textil). Sus fuentes eran diccionarios, artículos de gacetas y actas de academias, en particular, de la Academia de Ciencias de París y su Collection des $A r t s^{82}$. En este sentido, constituían una simple prolongación de las traducciones de esa misma colección publicadas por Campomanes en sus Discursos.

El dominio de las Memorias se extendió también a la Economía Política. En ellas se publicaron las traducciones de los tratados de Condillac (1778), Necker, (1783), Bigot de Saint-Croix (1791), Justi (1791) y Turgot, junto a su Édit de abolición de los gremios $(1791)^{83}$. Todo ello representó un salto notable en la historia de la prensa económica española: por vez primera, se daban a la luz tratados completos de Economía Política. Además, todas las traducciones eran de excelente calidad, sin apenas censuras y, a excepción de la de Justi, íntegras. Se trataba, asimismo, de las obras de autores muy significados en la explicación del funcionamiento de la sociedad comercial (Condillac y Turgot) o para el desarrollo de las reformas oficiales relativas al comercio de los granos (Necker) y la libertad de trabajo (Turgot y Saint-Croix). Con todo ello, Suárez no hacía sino seguir las pautas generales de la cultura económica española de los años ochenta. En esos años, en particular, gracias a la traducción, se conoció una auténtica «explosión» en la diseminación de textos foráneos, ya más allá de las posiciones del círculo

81. Idem, pp. 97-98.

82. Pinilla, J.: «Les sources des Memorias instructivas y curiosas (1778-1791)», Cuadernos de Filología Francesa, 22, 2011, pp. 161-175.

83. MIC, vol. III, memorias n. XLI-XLIII, y vol. IV, n. XLV (Condillac); vol. VIII, n. LXXIII-LXXIV (Necker); vol. XII, n. CXII (Turgot) y n. CXIII (Bigot de Saint-Croix y Turgot); y vol. XII, n. CXVI (Justi). 
de Gournay ${ }^{84}$. Las traducciones publicadas en las Memorias formaban parte de ese mismo fenómeno. Ello convirtió a Suárez en uno de los traductores de textos económicos más prolíficos de la Ilustración española, aunque con toda probabilidad él no fuera el único autor material de esas versiones - en las actas de la Matritense se menciona la ayuda ocasional del socio Lorenzo Irisarri-. En cualquier caso, sus Memorias hubieron de ser elaboradas siguiendo directrices precisas de la Matritense. Los textos traducidos no solo fueron objeto de censura en su seno ${ }^{85}$, sino que eran bien conocidos entre sus autoridades más influyentes, entre ellos Campomanes y Jovellanos. Esta apuesta por la Economía Política era más lógica aún si tenemos presente que en 1779 la conservadora oeconomie volvía a encontrar una vez más como aliado al ubicuo Nifo, quien aprovechó el inicio de la nueva guerra con Gran Bretaña para reeditar su Correo General de la Europa ${ }^{86}$.

La meritoria labor de Suárez -además de las Memorias, tradujo una quincena de obras de Nollet, Macquer, Duhamel de Monceau y otros científicos de la Ilustración europea-se revaloriza si tenemos presente que sus Memorias aguantaron las turbulencias derivadas de la Revolución francesa. En 1791, en pleno reflujo de las posiciones ilustradas en España, editó en sus Memorias una excelente traducción del emblemático tratado de Turgot. Nadie mejor que Suárez refleja la infelicidad de esos periodistas pioneros, que ofrecieron su pluma y su dinero para lograr que la prensa contribuyera, en palabras de Jovellanos, a «acelerar esta general tendencia que se advierte entre nosotros hacia el estudio de la Economía» ${ }^{87}$. Su muerte en 1791 coincidió con la ley de Floridablanca de febrero de ese año prohibiendo la prensa y sucedió en una situación de gran penuria. Después de trabajar durante décadas para la Junta de Comercio, apenas había obtenido como honores la concesión en 1784 de una plaza de agente fiscal en ella.

\section{LOS PROYECTOS DE LA SOCIEDAD MATRITENSE}

Mientras todo ello sucedía, en 1786-1787 la Matritense debatía sobre la conveniencia de promover una gaceta exclusivamente económica ${ }^{88}$. Subyacía a ese propósito la percepción de que, no sólo las Memorias de Suárez, sino las grandes iniciativas periodísticas de esos años-El Censor (1781-1787), el Memorial Literario (1784-1791), El Correo de los Ciegos (1786-1791) o El Espíritu de los

84. Para una visión general, vid. Llombart: «Traducciones», op. cit. 674).

85. En 1786 la Matritense nombró como censor a Diego Notario (AHN, Consejos, leg. 50

86. Fue en realidad una selección de discursos de esa publicación. Entre ellos se hallaba otra vez el emblemático de Linneo (vol. II, carta CVII), que volverá a reeditar en 1786.

87. Jovellanos: op. cit., p. 648.

88. Domergue: op. cit., pp. 201-231. 
mejores diarios literarios (1787-1791)- eran generalistas y estaban destinadas a públicos amplios. El debate hizo aflorar tres posiciones. Para Manuel José Marín la Matritense debía utilizar su centralidad en la red de sociedades económicas para promover una gaceta, semanal o bimensual, «nacional», consagrada a las novedades generadas por esas sociedades. A su vez, Jovellanos entendía que esas novedades «nacionales» serían insuficientes para completar una gaceta con esa periodicidad, por lo que apoyaba una opción mixta, que incluyera la traducción de extractos extranjeros. Por último, Pérez Villamil apostaba por un periódico orientado hacia los debates teóricos ${ }^{89}$. Las discrepancias se extendieron también al ámbito doctrinal. El dictamen de Jovellanos evocaba a Condillac: la gaceta debía de centrarse en las «relaciones políticas» entre el gobierno y la economía, "considerados relativamente el uno con el otro» ${ }^{90}$. En cambio, la propuesta de Villamil parecía más próxima a la fisiocracia, cuyas iniciativas periodísticas dirigidas a defender las ventajas del royaume agricole frente a las monarquías y repúblicas comerciales no habían tenido eco en España hasta esa fecha ${ }^{91}$. Como consecuencia de este debate, a finales de 1787 la Matritense decidió promover una doble publicación: una gaceta y un mercurio económico mensual, siendo este segundo una especie de hoja con extractos de discursos.

A través de esa decisión la Matritense también parecía tratar de no verse desplazada por el «diluvio de obras de todas clases que inundan la República literaria» ${ }^{92}$. En efecto, al mismo tiempo que en esos años emergía una prensa provincial, con una presencia especialmente notable en Andalucía y en los antiguos territorios de la Corona de Aragón ${ }^{93}$, entre 1786 y 1789 se activaron al menos cinco proyectos de gacetas económicas. Es muy significativo que Nifo volviera a hacerse presente en este momento clave de la historia de la prensa económica española. En su nueva iniciativa, un diario titulado el $A \tilde{n} o$ literario ${ }^{94}$, defendía su papel pionero como traductor de «obras exquisitas» sobre agricultura, comercio y artes: «en el día están las gentes algo inclinadas a la lectura, mucho más que cuando dicho

89. El «Dictamen» de Jovellanos era del 10 de febrero de 1786.

90. No es casual que su dictamen fuera realizado cuando el tratado de Condillac conocía una diseminación muy intensa. Traducido en 1778 en las MIC, en diciembre de 1785 la Matritense había sido reclamada por el Consejo de Castilla para realizar la censura de una nueva traducción, enviada por José Baucis, vecino de Madrid. Fue el propio Jovellanos quien aconsejó su publicación, a pesar de hallarse traducido, pues contenía una «excelente doctrina económica».

91. Se ratifica así la escasa presencia de los économistes en España; vid. Lluch, E., Argemí, Ll.: Agronomía y fisiocracia en España. Valencia, 1985.

92. AHN, Consejos, leg. 5 552-8.

93. La más notable y perdurable fue el Diario de Barcelona, fundado en 1792 por el napolitano Pedro Pablo Usson con el apoyo del Ayuntamiento de la ciudad. Sobre el contenido de su rúbrica sobre «economía y comercio», vid. Lluch: El pensament, op. cit., pp. 79 y ss.

94. AHN, Consejos, leg. 50674. 
Nifo estableció el Diario Universal, Curioso, Erudito, etc.». Ahora bien, cuando meses después el Consejo le requirió una muestra de su nuevo diario, él optó por reeditar, por tercera vez, su Correo General de la Europa ${ }^{95}$.

Entre los otros cuatros promotores figuraban publicistas destacados, como Cristóbal Cladera o Marien Arróspide ${ }^{96}$. El «comercio», en su vertiente teórica o práctica, aparecía en sus iniciativas entremezclado con artículos sobre ciencias, literatura y otras disciplinas. La única excepción era la propuesta del comerciante bilbaíno Marien, consistente en editar una «Biblioteca completa de comercio» partiendo de los manuales de comerciantes. Ello pone de relieve el carácter fronterizo de algunas de estas iniciativas con otras destinadas a diseminar los conocimientos comerciales y económicos a través de diccionarios o colecciones alfabéticas ${ }^{97}$. No obstante, la estrategia de los censores fue, en general, contraria a las mismas. Teniendo sin duda presente la experiencia de la etapa previa, se aducía en su negativa el previsible fracaso de las iniciativas debido a su ambición, inexperiencia, falta de profesionalidad y, solo marginalmente, la presencia de afirmaciones «arriesgadas» desde la óptica de la ortodoxia religiosa ${ }^{98}$. De hecho, de todas esas iniciativas, tan solo un volumen de los siete prometidos por Marien terminó viendo la luz. Los expedientes de estas publicaciones rechazadas ponen de manifiesto que la prensa se había convertido en un fértil terreno para la promoción social; pero también, al mismo tiempo, en un campo de batalla para las aspiraciones ilustradas. Más aún cuando, en palabras de Larriba, la «hidra periodística» crecía

95. Todo ello confirma a Nifo como uno de los referentes centrales de la Ilustración española anclada en la corriente del agrarismo cristiano, absolutista y profundamente anticomercial, que tenía sus fuentes en autores como Fleury, Pluche o Fénelon; vid. Rothkrug, L.: Opposition to Louis XIV. The Political and Social Origins of the French Enlightenment. Princeton, Princeton University Press, 1965, pp. 234-298.

96. Los proyectos eran los siguientes: «Biblioteca periódica y elemental de ciencias, artes, literatura y comercio», por Cristóbal Cladera, diciembre de 1786 (AHN, Consejos, leg. 5 552-8); «Biblioteca completa del comercio», junto a un papel quincenal sobre el comercio universal, por Marien Arróspide, primavera de 1788 (AHN, Consejos, leg. 5 554-42); «Diario enciclopédico de las ciencias, bellas letras, artes y oficios, agricultura, economía y comercio", por un científico irlandés y un matemático francés, noviembre de 1788 (AHN, Consejos, leg. 3 242-22); «Diario de ciencias, agricultura, comercio, artes y oficios», por dos escritores franceses y un científico irlandés, febrero de 1789 (AHN, Consejos, leg. 5 555-84). Todavía en 1804, dos particulares proponían una «Biblioteca rural o Diccionario completo del labrador», sobre la base de un «solo pliego», trisemanal, para divulgar los artículos del Semanario de agricultura y de artes; una Orden de 1809 lo prohibió (AHN, Consejos, leg. 5 567-4).

97. Nos remitimos a Astigarraga, J. y Zabalza, J.: «Los diccionarios de Comercio y Economía en el siglo XVIII español», Revista de Historia Industrial, 35, 2007, pp. 13-46, y «Economía Política y Comercio en los diccionarios y la literatura enciclopédica española del siglo XVIII», Bulletin Hispanique, 111 (2), 2009, pp. 387-427.

98. AHN, Consejos, leg. 5 552-8.

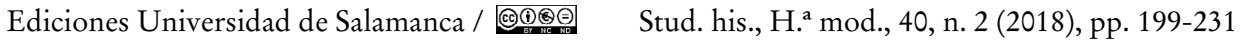


con el viento a favor del gobierno, y la Inquisición, aun conservando formalmente su poder censor, era, ya por mero desbordamiento, incapaz de cortarle la cabeza a su debido tiempo ${ }^{99}$.

\section{EL CORREO MERCANTIL DE ESPAÑA Y SUS INDIAS (1792-1808)}

La iniciativa de la Matritense quedó finalmente sin efecto. No obstante, la densidad de los sucesos acaecidos en 1791-1792 -fallecimiento de Suárez; orden de febrero de 1791 de Floridablanca silenciando la prensa; revocación discreta de la misma un año después por Aranda- desembocó en la aparición en octubre de 1792 del primer ejemplar de El Correo Mercantil de España y sus Indias (1792-1808) ${ }^{100}$. Se trató de un periódico bisemanal, de excelente factura y cuyo contenido, por vez primera, versaba mayoritariamente sobre cuestiones teóricas y prácticas del «comercio» y las artes, alcanzando además todo el espectro del imperio. Su creación debe analizarse en el contexto más amplio de la fundación, bajo el Ministerio de Lerena, del Departamento de la Balanza de Comercio. El Correo recayó sobre dos de sus más destacados publicistas, Diego María Gallard y Eugenio Larruga (Zaragoza, 1747-Madrid, 1803); en particular sobre el primero, Secretario de la Balanza, quien fue su director estable -excepto durante 1795-1799-.

Así pues, a diferencia de sus predecesores, el periódico respondió a una iniciativa oficial, incluyendo en ello su financiación. Ello explica su prolongada estabilidad: se mantuvo vigente más de una quincena de años, hasta 1808. Al tiempo que sus contenidos eran examinados -y censurados- por la Secretaría de Hacienda, canalizaba información procedente de la tupida red de instituciones oficiales y semioficiales, sociedades económicas, consulados y todo tipo de organismos dependientes de la Junta de Comercio. De hecho, sus contenidos, organizados en torno a las secciones de agricultura, artes y comercio, reunían también noticias sobre esas instituciones, junto a informaciones legislativas, artículos -originales y traducidos- y reseñas. De esta manera, se configuraba como un instrumento «político» para, una vez culminados los decretos del comercio libre $(1765,1778$ y 1788), mantener cosido el comercio español a ambos lados del Atlántico.

En cualquier caso, la creación de El Correo no es ajena a las más de tres décadas previas de esas iniciativas, tan fugaces como vacilantes, de periódicos con contenido económico; más bien, parece su desenlace natural. Esta cuestión es perceptible

99. Larriba, E.: «Inquisición», op. cit., pp. 77-92, y Domergue, L.: Censure et Lumières dans l'Espagne de Charles III. París, 1982, pp. 147-192.

100. Nos remitimos a Enciso, L. M.: Prensa económica, op. cit. Su concepción pudo inspirarse en el JC. Al igual que su director Serionne, Gallard publicó a partir de 1795 un Almanaque Mercantil anual, complementario a El Correo.

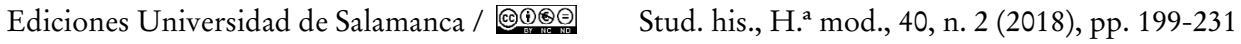


a un doble nivel. El primero alude a la aparición en España del profesional del periodista económico: si Nifo, Barberi, Saura o Suárez ya habían dado inicio a esa senda, con más motivo, Gallard y Larruga pueden ser considerados el origen definitivo de un género periodístico que no hará sino ganar adeptos a lo largo del siglo XIX. El segundo alude al «público». Es indiscutible que, a diferencia de la prensa económica predecesora, $E l$ Correo estaba diseñado para responder a un lector especializado: su composición en artículos e informaciones sobre artes aplicadas, comercio en sentido estricto y economía política convertía a la cabecera en particularmente atractiva para agentes económicos como comerciantes, empresarios o artesanos. De hecho, a diferencia de la prensa previa, se disponen de datos fehacientes sobre sus lectores. Larriba, tras analizar la relación de suscriptores de los seiscientos ejemplares de su tirada, ha concluido que contó con un éxito relativo entre funcionarios y comerciantes, vecinos de un contexto mayoritariamente urbano, tanto la capital y las ciudades de provincias como algunas de las principales urbes del imperio ${ }^{101}$. Su ejemplo pone de relieve que, como ocurrió con otros géneros periodísticos, no existió una correlación estrecha entre prensa y actividad profesional; pero ello no desdice que contribuyera a comenzar a forjar un público especializado. Y en ello la labor de la prensa que le precedió tampoco debe ser minusvalorada.

\section{CONCLUSIONES}

A lo largo de la segunda mitad del siglo XVIII España fue testigo de la aparición de un nuevo género: la prensa económica. Sus orígenes se remontan a las cabeceras de Nifo de inicios de los años sesenta. El proceso culminó tres décadas después con la aparición de El Correo Mercantil. En esos años, de manera gradual pero ininterrumpida, la prensa, aún sin perder su naturaleza polivalente, comenzó a integrar en sus contenidos artículos sobre Economía Política. Ello no dejaba de ser un reflejo del proceso coetáneo más amplio de emergencia en España de esa nueva ciencia. Estos primeros pasos de la prensa económica, como un género diferenciado de la estrictamente comercial y la versada sobre las artes aplicadas, siguieron una senda similar a la de la prensa general, con una primera fase, entre 1762 y 1771, de proyectos efímeros y titubeantes, y otra posterior, iniciada en 1776, que representó un auténtico turning point en la historia de la prensa económica española.

101. Larriba, E.: El público, op. cit., pp. 74-78, 321-330; vid. asimismo, Enciso: Prensa económica, op. cit., pp. 74-78. Puede confrontarse con los suscriptores de los dos periódicos de mayor tirada de la época, la Gaceta y el Mercurio, con alrededor de 10000 y 5000 ejemplares, respectivamente: Enciso, L. M.: La Gaceta de Madrid y el Mercurio Histórico y Político, 17561781, Valladolid, 1957, pp. 73-87. 
Esa prensa fue, durante toda su andadura, un fértil campo de disputas ideológicas. Lo más significativo a este respecto fue la gradual disipación de la visión conservadora de la oeconomie, omnipresente en las cabeceras de Nifo, en favor de una prensa que se fue abriendo sin ambages a la nueva publicística económica europea. Más en concreto, de la mano de Barberi, Saura, Suárez y los miembros de la Sociedad Matritense, y apoyándose principalmente en dos periódicos franceses -el JOE y el JC-, la prensa se erigió en un auténtico altavoz de las corrientes ideológicas que nutrieron la corriente principal de la Ilustración económica española. Apenas existen ecos en aquella de la fisiocracia; sí, en cambio, del cameralismo (Bielfeld) o de los autores del círculo de Gournay (Forbonnais, Danguel, Coyer, Serionne), en un primer momento, y de una pluralidad de economistas muy significativos en el posterior (Turgot, Condillac, Necker).

A este afianzamiento gradual de la prensa económica no fue ajena la consideración creciente que fue ganando ésta como un factor insoslayable de «Ilustración». En el último cuarto de siglo, la diseminación de los conocimientos económicopolíticos se insertaba en un programa más amplio en el que la prensa operaba en conjunción con las traducciones y las sociedades económicas. Todas ellas estaban destinadas a convertirse en auténticas incubadoras del «espacio» y la «opinión» públicos, así como en piezas claves para ganar adeptos en apoyo de las reformas. No extraña así que, en ese período, la prensa económica fuera tutelada desde el poder, por instituciones como la Junta de Comercio o la Sociedad Matritense. Y, tampoco que contribuyera a forjar gradualmente la aparición del público y del periodista profesional especializados en Economía, convirtiéndose así en una poderosa plataforma para los desarrollos de los que será testigo el siglo XIX.

\section{BIBLIOGRAFÍA ${ }^{102}$}

Aguilar Piñal, F.: La prensa española en el siglo XVIII. Diarios, revistas y pronósticos. Madrid, CSIC, 1978.

Aguilar Piñal, F..: «Un traductor de la ciencia ilustrada: Suárez y Núñez», Cuadernos Dieciochistas, 7, 2006, pp. 87-112.

Albertone, M.: «Fondements économiques de la réflexion du XVIIIe siècle autor de l'homme porteur de droits»,Clio@Themis, 3, 2010, http://www.cliothemis.com/ Clio-Themis-numero-3.

Álvarez Barrientos, J.: «El periodista en la España del siglo XVIII y la profesionalidad del escritor», Estudios de Historia Social, 51-53, 1990, pp. 29-39.

102. Las abreviaturas de la prensa citada en el texto figuran al final de las referencias bibliográficas de los respectivos periódicos. 
Astigarraga, J.: «La traduction au service de la Politique. Le succès de Jacques Necker dans les Lumières espagnoles», Annales Historiques de la Révolution Française, 364, 2011, pp. 3-27.

Astigarraga, J.: «Un nuevo sistema económico para la Monarquía española. Las Reflexiones sobre el estado actual del comercio de España (1761) de Simón de Aragorri», Revista de Historia Industrial, 52, 2013, pp. 13-44.

Astigarraga, J.: «Forbonnais and the Discovery of the Science of Commerce in Spain (1755-1765)», History of European Ideas, 4 (8), 2014, pp. 1087-1107.

Astigarraga, J.: «Les traductions espagnoles des normes législatives et des écrits économiques de Turgot (1774-1791)», Annales Historiques de la Révolution Française, 384, 2016, pp. 27-51.

Astigarraga, J.: «Oikonomia y «Comercio» en la versión española del Journal Oeconomique: los Discursos Mercuriales (1752-1756) de Graef», Cuadernos de Historia Moderna, 42 (1), 2017, pp. 39-68.

Astigarraga, J. y Zabalza, J.: «Los diccionarios de Comercio y Economía en el siglo XVIII español», Revista de Historia Industrial, 35, 2007, pp. 13-46.

Astigarraga, J. y Zabalza, J.: «Economía Política y Comercio en los diccionarios y la literatura enciclopédica española del siglo XVIII», Bulletin Hispanique, 111 (2), 2009, pp. 387-427.

Barberi, M. A.: Miscelánea política. Madrid, Antonio Muñoz del Valle, s. a. [1763-1764] (MP). BNE: 3/57543(1).

Barberi, M. A.: Cartas político-instructivas sobre varios puntos de la felicidad pública. Madrid, Imprenta de Francisco Xavier García, 1770 (CPI). BNE: VE/356(38).

Bielfeld, J. F. von, Barón de: Institutions politiques. 2 t. en 1 vol., La Haya, Pierre Gosse, 1760.

Campomanes, P. Rodríguez, Conde de: Apéndice a la Educación Popular. 4 vols., Madrid, Antonio de Sancha, 1775-1777.

Charles, L. et al (Eds.): Le cercle de Vicent de Gournay. París, INED, 2011.

Checa, A.: «La terminología periodística: sus orígenes y su consolidación», Cuadernos de Ilustración al Romanticismo, 16, 2010, pp. 1-10, http://revistas.uca.es/index.php/ cir/article/view/185.

Child, J.: Traités sur le commerce. Ámsterdam y París, J. Néaulme, 1754.

Clavijo, J.: El Pensador (1762-1767). Ed. facsimile, Tenerife, Sociedad Económica de Amigos del País de Tenerife, 1999-2001 (EP).

Cubié, J.: Semanario económico. Madrid, 1777-1778 (seudónimo: Biceu), (SE, Cubié). BNE: 2/1908.

Domergue, L.: Jovellanos à la Société Économique des Amis du Pays de Madrid. Toulouse, Université de Toulouse, 1971.

Domergue, L.: Censure et Lumières dans l'Espagne de Charles III. París, CNRS, 1982.

Dziembowski, E.: Un nouveau patriotisme français, 1750-1770. Oxford, Voltaire Foundation, 1998.

Dziembowski, E.: «Le peuple français instruit: Edme-Jacques Genet et la traduction des écrits politiques britanniques pendant la guerre de Sept Ans», en Thomson, A. et al.

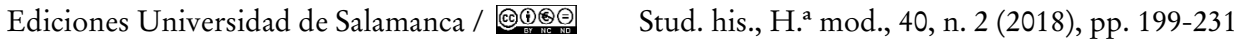


(Eds.): Cultural transfers: France and Britain in the long eighteenth-century. Oxford, Voltaire Foundation, 2010, pp. 175-188.

El pensador matritense. Discursos criticos sobre todos los asuntos que comprende la sociedad civil. 5 vols., Barcelona, Francisco Generas, c. 1780 (EPM). BNE: 2/51850-3.

Enciso, L. M.: Nipho y el periodismo español del siglo XVIII. Valladolid, Universidad de Valladolid, 1956.

Enciso, L. M.: La Gaceta de Madrid y el Mercurio Histórico y Político, 1756-1781. Valladolid, 1957.

Enciso, L. M.: Prensa económica del XVIII: El Correo Mercantil de España y sus Indias. Valladolid, Universidad de Valladolid, 1958.

Enciso, L. M.: Compases finales de la cultura ilustrada en la época de Carlos IV. Madrid, Real Academia de la Historia, 2013.

État politique actuel de l'Angleterre. 10 vols., s. 1., s. e., 1757-1759 (EPA). BNF: FRBNF41479678.

Fougeret de Montbron, J.-L.: Préservatif contre l'anglomanie. Menorca, 1757.

Gauci, P.: The Politics of Trade: the Overseas Merchant in State and Society, 1660-1720. Oxford, 2001.

Gee, J.: Consideraciones sobre el comercio y la navegación de la Gran Bretaña. Madrid, Juan de San Martín, 1753.

Graef, J. E.: Discursos Mercuriales. Madrid, Agustín de Gordejuela, 1752, 1755-1756 (DM). BNE: REVMICRO/1636 (1 y 2).

Grieder, J.: Anglomania in France 1740-1789. Ginebra, Droz, 1985.

Guinard, P. F.: La presse espagnole de 1737 à 1791. París, Centre de Recherches Hispaniques, 1973.

Hasquin, H.: «Jacques Accarias de Serionne, économiste et publiciste français au service des Pays-Bas Autrichiens», en Mortier, R. et al. (Eds.): Études sur le XVIIIe siécle. Bruselas, Université de Bruxelles, 1974, pp. 159-170.

Journal Oeconomique. París, 1751-1772 (JOE). BNF: FRBNF32801251.

Journal de Commerce. 20 vols., Bruselas, J. Vanden Berghen, 1759-1760; Bruselas, P. de Bast, 1761 (JC). BNF: FRBNF39312231.

Jovellanos, G. M.: Obras completas. Tomo X: escritos económicos. Llombart, V. et al. (Eds.), Gijón, Ayuntamiento de Gijón, Instituto Feijoo de Estudios del Siglo XVIII y KRK, 2008.

Larriba, E.: «Las Reales Sociedades Económicas de Amigos del País y la prensa de la Ilustración», en Aubert, P. et. al. (Eds.): Les élites et la presse en Espagne et en Amerique Latine. Des Lumiéres à la seconde guerre mondiale. Madrid, Casa de Velázquez, 2004, pp. 33-49.

Larriba, E.: «Inquisición y prensa periódica en la segunda mitad del siglo XVIII», Cuadernos de Ilustración y Romanticismo, 13, 2005, pp. 77-92, http://revistas.uca.es/index. $\mathrm{php} / \mathrm{cir} / \mathrm{article} / \mathrm{view} / 257 / 241 \#$.

Ediciones Universidad de Salamanca / 요 Stud. his., H. ${ }^{a}$ mod., 40, n. 2 (2018), pp. 199-231 
Larriba, E.: «Las aspiraciones a la libertad de imprenta en la segunda mitad del siglo XVIII», en Larriba, E. et. al. (Eds.): El nacimiento de la libertad de imprenta. Madrid, Sílex, 2012, pp. 19-41.

Larriba, E.: El público de la prensa en España a finales del siglo XVIII (1781-1808). Zaragoza, Prensas Universitarias de Zaragoza, 2013.

Le Guellec, M.: Presse et culture dans l'Espagne des Lumières. Madrid, Casa de Velázquez, 2016.

Lluch, E.: El pensament economic a Catalunya (1760-1840). Barcelona, Edicions 62, 1973. Lluch, E.: Las Españas vencidas del Siglo XVIII. Barcelona, Crítica, 1999.

Lluch, E. y Argemí, Ll.: Agronomía y fisiocracia en España. Valencia, Alfons el Magnánim, 1985.

Llombart, V.: «Traducciones españolas de Economía Política (1700-1812): catálogo bibliográfico y una nueva perspectiva», CROMOHS, 9, 2004, pp. 1-14,

Llombart, V.: «Traspassar fronteres, traduir les llums: Economia i traducció a l'Espanya del secle XVIII», en Claret, J. (Coord.): Miscellània Ernest Lluch i Martin. Barcelona, Fundaciò Ernest Lluch, 2006, vol. II, pp. 119-134.

Maestre, J. M., Díaz, M. A. y Romero, A. (Eds.): Francisco Mariano Nipho. El nacimiento de la prensa y de la crítica literaria periodística en la España del siglo XVIII. Alcañiz y Madrid, CSIC e Instituto de Estudios Humanísticos, 2015.

Mccusker, J. J. y Gravesteijn, C.: The Beginnings of Commercial and Financial Journalism. Ámsterdam, NEHA, 1991.

Mirabeau, V. Riquetti, Marqués de: L'Ami des hommes, ou Traité de la Population. 3 vols., Avignon, s. e., 1758-1760.

Mokyr, J.: The Enlightened Economy. Britain and the Industrial Revolution, 1700-1850. New Haven y Londres, Yale University Press, 2009.

Nifo, F. M.: Correo General de España. 4 vols., Madrid, Escribano, 1769 [1770], (CGE). BNE: REVMCF/18.

Nifo, F. M.: Correo General, Histórico, Literario y Económico de la Europa (en continuación de la Estafeta de Londres). 4 vols., Madrid, Gabriel Ramírez, 1763 (CGH). BNE: 3/21635-8.

Nifo, F. M.: Descripción natural, geográfica, y económica de todos los pueblos de España, en continuación del Correo General, etc. 3 vols., Madrid, 1771 (DNG). BNE: REVMCF/47.

Nifo, F. M.: Diario noticioso, curioso-erudito, y comercial, público, y económico. Madrid, Imprenta del Diario, s.a. [1758] (DN). BNE: REVMICRO/9 (1-22).

Nifo, F. M.: Diario estranjero. Madrid, Gabriel Ramírez, 1763 (DE). BNE: REVMI$\mathrm{CRO} / 1641$.

Nifo, F. M.: Estafeta de Londres. 2 vols., Madrid, Gabriel Ramírez, 1762 (EL). 2/58547 (4).

Nifo, F. M.: Estafeta de Londres, y extracto del Correo General de Europa. 2 vols., $2^{a}$ ed., Madrid, Miguel Escribano, 1779; 2 vols., $3^{a}$ ed., Madrid, Miguel Escribano, 1786 (ELE). BNE: 2/39658-9. 
Nifo, F. M.: El hablador juicioso, y crítico imparcial. Madrid, Imprenta de Francisco Xavier García, 1763 (seudónimo: Abate J. Langlet), (EHJ). BNE: REVMICRO/1647(1-2).

Ocampo, J.: «El Semanario Económico (1765-1767): a la Ilustración por la utilidad», El Argonauta español, 10, 2013, http://argonauta.revues.org/1926.

Orain, A.: «Le Journal Oeconomique, le cercle de Gournay et le pouvoir monarchique: quelques preuves matérielles d'un lien organique», Dix-Huitième Siècle, 45, 2013, pp. 565-583.

Pinilla, J.: «Les sources des Memorias instructivas y curiosas (1778-1791)», Cuadernos de Filología Francesa, 22, 2011, pp. 161-175.

Rothkrug, L.: Opposition to Louis XIV. The Political and Social Origins of the French Enlightenment. Princeton, Princeton University Press, 1965.

Sáiz, M. D.: Historia del periodismo en España. Vol. 1. Los orígenes. El Siglo XVIII. Madrid, Alianza, 1983.

Saura, J. P.: Semanario Económico. 3 vols., Madrid, Imprenta de Andrés Ramírez, 17651766 (seudónimo: Araus), (SE, Saura). BNE: 2/1905-1907.

Sempere, J.: Ensayo de una biblioteca española de los mejores escritores del reinado de Carlos III. 6 vols., Madrid, Imprenta Real, 1785-1789.

Sgard, J. (Ed.): Dictionnaire des journalistes (1600-1789), http://dictionnaire-journalistes. gazettes18e.fr/journaliste.

Sgard, J. (Ed.): Dictionnaire des journaux (1600-1789), http://dictionnaire-journaux. gazettes18e.fr/journal.

Steiner, Ph.: «Les grandes revues économiques de langue française au XVIIIème siècle (1751-1776)», en Marco, L. (Ed.): Les revues françaises d'économie politique XVIIIeXIXe siècle. París, L'Harmatan, 1996, pp. 35-78.

Suárez y Núñez, J.: Memorias instructivas, y curiosas. 12 vols., Madrid, Pedro Marín, 1778-1790; Antonio Fernández 1791 (MIC). BNE: 3/50239-50250.

Urzainqui, I.: «Un nuevo instrumento cultural: la prensa periódica», en Álvarez Barrientos, J. et al (Eds.): La República de las Letras en la España del Siglo XVIII. Madrid, 1995, pp. 125-216.

Urzainqui, I.: «Periodista-espectador en la España de las Luces. La conciencia de un género nuevo de escritura periodística», El argonauta español, 6, 2009, https://argonauta. revues.org/516.

Urzainqui, I.: «Diálogo entre periodistas (1737-1770)», en Maestre, J. M. et al. (Eds.): Francisco Mariano Nipho. El nacimiento de la prensa y de la crítica literaria periodística en la España del siglo XVIII. Alcañiz y Madrid, CSIC e Instituto de Estudios Humanísticos, 2014, pp. 375-418.

Usoz, J.: «Mateo Antonio Barberi: el ideario de la Junta General de Comercio en Aragón». Cuadernos Aragoneses de Economía, 8 (2), 1998, pp. 501-523.

Ediciones Universidad de Salamanca / @®®@ Stud. his., H. ${ }^{a}$ mod., 40, n. 2 (2018), pp. 199-231 